\title{
Global analysis of continental boundary layer new particle formation based on long-term measurements
}

Tuomo Nieminen $^{1,2}$, Veli-Matti Kerminen ${ }^{1}$, Tuukka Petäjä ${ }^{1}$, Pasi P. Aalto ${ }^{1}$, Mikhail Arshinov ${ }^{3}$, Eija Asmi $^{4,5}$, Urs Baltensperger $^{6}$, David C. S. Beddows ${ }^{7}$, Johan Paul Beukes ${ }^{8}$, Don Collins ${ }^{9}$, Aijun Ding ${ }^{10}$, Roy M. Harrison ${ }^{7,11}$, Bas Henzing ${ }^{12}$, Rakesh Hooda ${ }^{4,13}$, Min Hu ${ }^{14}$, Urmas Hõrrak ${ }^{15}$, Niku Kivekäs ${ }^{4}$, Kaupo Komsaare ${ }^{15}$, Radovan Krejci ${ }^{16}$, Adam Kristensson ${ }^{17}$, Lauri Laakso ${ }^{4,8}$, Ari Laaksonen ${ }^{4,2}$, W. Richard Leaitch ${ }^{18}$, Heikki Lihavainen ${ }^{4}$,

Nikolaos Mihalopoulos ${ }^{19}$, Zoltán Németh ${ }^{20}$, Wei Nie $^{10}$, Colin O'Dowd $^{21}$, Imre Salma ${ }^{20}$, Karine Sellegrii ${ }^{22}$,

Birgitta Svenningsson $^{17}$, Erik Swietlicki ${ }^{17}$, Peter Tunved ${ }^{16}$, Vidmantas Ulevicius ${ }^{23}$, Ville Vakkari ${ }^{4}$, Marko Vana ${ }^{15}$, Alfred Wiedensohler ${ }^{24}$, Zhijun Wu ${ }^{14}$, Annele Virtanen ${ }^{2}$, and Markku Kulmala ${ }^{1,10,25}$

${ }^{1}$ Institute for Atmospheric and Earth System Research/Physics, Faculty of Science, University of Helsinki, Helsinki, Finland

${ }^{2}$ Department of Applied Physics, University of Eastern Finland, Kuopio, Finland

${ }^{3}$ V.E. Zuev Institute of Atmospheric Optics SB RAS, Tomsk, Russia

${ }^{4}$ Finnish Meteorological Institute, Helsinki, Finland

${ }^{5}$ Servicio Meteorológico Nacional, Buenos Aires, Argentina

${ }^{6}$ Laboratory of Atmospheric Chemistry, Paul Scherrer Institute, Villigen, Switzerland

${ }^{7}$ School of Geography, Earth and Environmental Sciences, University of Birmingham, Birmingham, UK

${ }^{8}$ Unit for Environmental Sciences and Management, North-West University, Potchefstroom, South Africa

${ }^{9}$ Department of Atmospheric Sciences, Texas A\&M University, College Station, Texas, USA

${ }^{10}$ Joint International Research Laboratory of Atmospheric and Earth System Sciences, School of Atmospheric Sciences, Nanjing University, Nanjing 210023, China

${ }^{11}$ Department of Environmental Sciences/Center of Excellence in Environmental Studies, King Abdulaziz University, PO Box 80203, Jeddah, 21589, Saudi Arabia

${ }^{12}$ Netherlands Organization for Applied Scientific Research (TNO), Utrecht, the Netherlands

${ }^{13}$ The Energy and Resources Institute, IHC, Lodhi Road, New Delhi, India

${ }^{14}$ State Key Joint Laboratory of Environmental Simulation and Pollution Control, College of Environmental Sciences and Engineering, Peking University, Beijing 100871, China

${ }^{15}$ Institute of Physics, University of Tartu, Tartu, Estonia

${ }^{16}$ Department of Environmental Science and Analytical Chemistry \& Bolin Centre of Climate Research,

Stockholm University, Stockholm, Sweden

${ }^{17}$ Department of Physics, Lund University, Lund, Sweden

${ }^{18}$ Climate Research Division, Environment and Climate Change Canada, Toronto, Canada

${ }^{19}$ Department of Chemistry, University of Crete, Heraklion, Greece

${ }^{20}$ Institute of Chemistry, Eötvös University, Budapest, Hungary

${ }^{21}$ School of Physics and Centre for Climate and Air Pollution Studies, National University of Ireland Galway, Galway, Ireland

${ }^{22}$ Laboratoire de Météorologie Physique, Observatoire de Physique du Globe de Clermont-Ferrand,

Université Clermont-Auvergne, CNRS UMR6016, Aubière, France

${ }^{23}$ Department of Environmental Research, SRI Center for Physical Sciences and Technology, Vilnius, Lithuania

${ }^{24}$ Leibniz Institute for Tropospheric Research, Leipzig, Germany

${ }^{25}$ Aerosol and Haze Laboratory, Beijing Advanced Innovation Center for Soft Matter Science and Engineering,

Beijing University of Chemical Technology, Beijing, China

Correspondence: Tuomo Nieminen (tuomo.nieminen@uef.fi)

Received: 23 March 2018 - Discussion started: 12 April 2018

Revised: 10 September 2018 - Accepted: 20 September 2018 - Published: 12 October 2018 


\begin{abstract}
Atmospheric new particle formation (NPF) is an important phenomenon in terms of global particle number concentrations. Here we investigated the frequency of NPF, formation rates of $10 \mathrm{~nm}$ particles, and growth rates in the size range of 10-25 nm using at least 1 year of aerosol number size-distribution observations at 36 different locations around the world. The majority of these measurement sites are in the Northern Hemisphere. We found that the NPF frequency has a strong seasonal variability. At the measurement sites analyzed in this study, NPF occurs most frequently in March-May (on about $30 \%$ of the days) and least frequently in December-February (about $10 \%$ of the days). The median formation rate of $10 \mathrm{~nm}$ particles varies by about 3 orders of magnitude $\left(0.01-10 \mathrm{~cm}^{-3} \mathrm{~s}^{-1}\right)$ and the growth rate by about an order of magnitude $\left(1-10 \mathrm{~nm} \mathrm{~h}^{-1}\right)$. The smallest values of both formation and growth rates were observed at polar sites and the largest ones in urban environments or anthropogenically influenced rural sites. The correlation between the NPF event frequency and the particle formation and growth rate was at best moderate among the different measurement sites, as well as among the sites belonging to a certain environmental regime. For a better understanding of atmospheric NPF and its regional importance, we would need more observational data from different urban areas in practically all parts of the world, from additional remote and rural locations in North America, Asia, and most of the Southern Hemisphere (especially Australia), from polar areas, and from at least a few locations over the oceans.
\end{abstract}

\section{Introduction}

Atmospheric aerosol particles have large impacts on air quality and human health (Apte et al., 2015; Brauer et al., 2015; Lelieveld et al., 2015; Zhang et al., 2015), on the current and future behavior of the climate system (IPCC, 2013; Shindell et al., 2015), and on climate-air quality interactions (Makkonen et al., 2012; Lacressonniere et al., 2014; Pietikäinen et al., 2015; Westervelt et al., 2015; Shen et al., 2017). According to large-scale model simulations, globally the most important source of atmospheric aerosol particles, at least in terms of their total number concentration but perhaps also of climate-relevant particles, is atmospheric new particle formation (NPF) and subsequent particle growth (e.g., Spracklen et al., 2008; Merikanto et al., 2009; Yu et al., 2010; Dunne et al., 2016). The relative importance of atmospheric NPF and primary emissions of aerosol particles into the atmosphere is, however, expected to vary regionally, as well as over the course of the year at any specific location.

Particle number size distribution measurements suggest that atmospheric boundary layer NPF is dominated by regional-scale NPF events. These events typically last for at least a few hours and simultaneously take place over dis- tances of hundreds of kilometers. Regional NPF events have been observed worldwide (e.g., Kulmala et al., 2004) and have also been characterized for a few relatively large areas in Europe, China, and North America (Manninen et al., 2010; Peng et al., 2014; Pietikäinen et al., 2014; Yu et al., 2015; Kulmala et al., 2016; Vana et al., 2016; Berland et al., 2017; Wang et al., 2017). In spite of numerous and an increasing number of high-quality atmospheric aerosol sizedistribution measurements, we are still lacking a global observationally based and internally consistent data set on atmospheric NPF that would cover the full annual cycle. Such data, especially from the Southern Hemisphere and tropics, would be valuable for multiple purposes, including global and regional model validation and complementary use of various modeling and measurement tools to enhance our general understanding of this phenomenon.

The primary goal of this study is to present the first globalscale picture of the main characteristics of atmospheric NPF based on atmospheric observations, including the seasonal frequency of regional NPF events and the formation and growth rates (GRs) of the newly formed particles during these events. More specifically, we aim to shed new light on the following questions:

1. How frequent is regional NPF in different types of continental environments overall and during the different seasons?

2. How do the particle formation and GRs, as recorded during the observed NPF events, vary with the type of environment and season?

3. To which extent are the NPF event frequency and the particle formation and GRs connected with each other?

In order to address our goal and specific questions, we gathered observations of atmospheric NPF from several measurement sites where at least 1 year of particle number size distribution measurements are available. Since the number of such sites turned out to be rather limited, we included sites with shorter data coverage, provided that these data could be parsed into a full seasonal cycle. Published peer-reviewed articles do not always present NPF event frequencies or particle formation and GRs. Therefore we collected observational data of submicron aerosol number size distributions from open databases (EBAS and ARM) and performed a standardized NPF analysis (see, e.g., Kulmala et al., 2012) for these data. This way, we were able to create an internally consistent data set on atmospheric NPF. This feature is not only crucial to the reliability of the result presented here but also extremely beneficial for any further use of our data. 
Table 1. List of the measurement sites included in this study, the station name abbreviation used to identify the sites in all the figures, station environment type, coordinates and altitude above sea level (a.s.1.), time period from which data were analyzed, availability of data (percentage of days with available data between start and end of the studied time period), instrumentation, and the particle size range. The instruments used to measure aerosol number size distributions were a differential mobility particle sizer (DMPS), scanning mobility particle sizer (SMPS), diffusion particle spectrometer (DPS), and electrical aerosol spectrometer (EAS).

\begin{tabular}{|c|c|c|c|c|c|c|c|c|c|}
\hline & \multicolumn{2}{|c|}{ Station name and abbreviation } & \multirow{2}{*}{$\begin{array}{l}\text { Environment } \\
\text { polar }\end{array}$} & Coordinates & \multirow{2}{*}{$\begin{array}{r}\begin{array}{r}\text { Altitude } \\
\text { (m a.s.1.) }\end{array} \\
474\end{array}$} & \multirow{2}{*}{$\begin{array}{l}\text { Time period } \\
2005-2013\end{array}$} & \multirow{2}{*}{$\begin{array}{r}\text { Data coverage } \\
(\%)\end{array}$} & \multirow{2}{*}{$\begin{array}{l}\text { Instrument } \\
\text { DMPS }\end{array}$} & \multirow{2}{*}{$\begin{array}{r}\begin{array}{r}\text { Size range } \\
(\mathrm{nm})\end{array} \\
10-800\end{array}$} \\
\hline 1 & Mt. Zeppelin, Norway & ZPL & & $78^{\circ} 56^{\prime} \mathrm{N}, 11^{\circ} 53^{\prime} \mathrm{E}$ & & & & & \\
\hline 2 & Dome-C, Antarctica & DMC & polar & $75^{\circ} 6^{\prime} \mathrm{S}, 123^{\circ} 23^{\prime} \mathrm{E}$ & 3200 & $2007-2009$ & 77 & DMPS & $10-620$ \\
\hline 3 & Alert, Canada & ALE & polar & $82^{\circ} 28^{\prime} \mathrm{N}, 62^{\circ} 30^{\prime} \mathrm{W}$ & 75 & $2012-2014$ & 96 & SMPS & $10-470$ \\
\hline 4 & Jungfraujoch, Switzerland & JFJ & high altitude & $46^{\circ} 33^{\prime} \mathrm{N}, 7^{\circ} 59^{\prime} \mathrm{E}$ & 3580 & $2008-2009$ & 87 & SMPS & $12-820$ \\
\hline 5 & Puy de Dome, France & PDD & high altitude & $45^{\circ} 46^{\prime} \mathrm{N}, 2^{\circ} 57^{\prime} \mathrm{E}$ & 1465 & $2008-2009$ & 92 & SMPS & $3-1000$ \\
\hline 6 & Pico Espejo, Venezuela & PIC & high altitude & $8^{\circ} 30^{\prime} \mathrm{N}, 71^{\circ} 6^{\prime} \mathrm{W}$ & 4775 & $2007-2009$ & 86 & DMPS & $10-470$ \\
\hline 7 & Mukteshwar, India & MUK & high altitude & $29^{\circ} 26^{\prime} \mathrm{N}, 79^{\circ} 37^{\prime} \mathrm{E}$ & 2180 & $2005-2014$ & 87 & DMPS & $10-750$ \\
\hline 8 & Mt. Waliguan, China & WLG & remote & $36^{\circ} 17^{\prime} \mathrm{N}, 100^{\circ} 54^{\prime} \mathrm{E}$ & 3816 & 2005-2007 & 68 & DMPS & $10-500$ \\
\hline 9 & Finokalia, Greece & FKL & remote & $35^{\circ} 18^{\prime} \mathrm{N}, 25^{\circ} 42^{\prime} \mathrm{E}$ & 235 & 2008-2012 & 76 & SMPS & $9-800$ \\
\hline 10 & Mace Head, Ireland & MHD & remote & $53^{\circ} 12^{\prime} \mathrm{N}, 9^{\circ} 48^{\prime} \mathrm{W}$ & 10 & 2005-2009 & 87 & SMPS & $8-470$ \\
\hline 11 & Värriö, Finland & VÄR & remote & $67^{\circ} 45^{\prime} \mathrm{N}, 29^{\circ} 36^{\prime} \mathrm{E}$ & 390 & 1997-2016 & 94 & DMPS & $3-860$ \\
\hline 12 & Pallas, Finland & PAL & remote & $67^{\circ} 58^{\prime} \mathrm{N}, 24^{\circ} 7^{\prime} \mathrm{E}$ & 565 & 2005-2014 & 82 & DMPS & $5-470$ \\
\hline 13 & Abisko, Sweden & $\mathrm{ABI}$ & remote & $68.35^{\circ} \mathrm{N}, 19.05^{\circ} \mathrm{E}$ & 380 & 2005-2007 & 49 & SMPS & $10-570$ \\
\hline 14 & Tiksi, Russia & TKS & remote & $71^{\circ} 36^{\prime} \mathrm{N}, 128^{\circ} 53^{\prime} \mathrm{E}$ & 10 & $2010-2012$ & 76 & DMPS & $7-500$ \\
\hline 15 & Hyytiälä, Finland & HYY & rural & $61^{\circ} 51^{\prime} \mathrm{N}, 24^{\circ} 17^{\prime} \mathrm{E}$ & 181 & $1996-2016$ & 96 & DMPS & $3-1000$ \\
\hline 16 & Aspvreten, Sweden & ASP & rural & $58^{\circ} 48^{\prime} \mathrm{N}, 17^{\circ} 24^{\prime} \mathrm{E}$ & 25 & $2006-2013$ & 94 & DMPS & $10-470$ \\
\hline 17 & Preila, Lithuania & PRL & rural & $55^{\circ} 24^{\prime} \mathrm{N}, 21^{\circ} 0^{\prime} \mathrm{E}$ & 10 & $2009-2013$ & 59 & SMPS & $8-850$ \\
\hline 18 & Tomsk, Russia & TMK & rural & $56^{\circ} 25^{\prime} \mathrm{N}, 84^{\circ} 4^{\prime} \mathrm{E}$ & 145 & 2011-2013 & 92 & DPS & $3-200$ \\
\hline 19 & Järvselja, Estonia & JRV & rural & $58^{\circ} 16^{\prime} \mathrm{N}, 27^{\circ} 16^{\prime} \mathrm{E}$ & 36 & $2012-2016$ & 79 & EAS & $3-1000$ \\
\hline 20 & Hohenpeissenberg, Germany & HPB & rural & $47^{\circ} 48^{\prime} \mathrm{N}, 11^{\circ} 1^{\prime} \mathrm{E}$ & 988 & $2008-2015$ & 91 & SMPS & $10-800$ \\
\hline 21 & Vavihill, Sweden & VHL & rural & $56^{\circ} 1^{\prime} \mathrm{N}, 13^{\circ} 9^{\prime} \mathrm{E}$ & 172 & $2008-2015$ & 84 & DMPS & $3-900$ \\
\hline 22 & K-puszta, Hungary & KPZ & rural & $46^{\circ} 58^{\prime} \mathrm{N}, 19^{\circ} 33^{\prime} \mathrm{E}$ & 125 & 2008-2014 & 78 & DMPS & $6-800$ \\
\hline 23 & Melpitz, Germany & MPZ & rural & $51^{\circ} 32^{\prime} \mathrm{N}, 12^{\circ} 54^{\prime} \mathrm{E}$ & 87 & $2008-2015$ & 87 & DMPS & $5-800$ \\
\hline 24 & San Pietro Capofiume, Italy & SPC & rural & $44^{\circ} 39^{\prime} \mathrm{N}, 11^{\circ} 37^{\prime} \mathrm{E}$ & 11 & $2002-2016$ & 78 & DMPS & $3-630$ \\
\hline 25 & Cabauw, Netherlands & CBW & rural & $51^{\circ} 18^{\prime} \mathrm{N}, 4^{\circ} 55^{\prime} \mathrm{E}$ & 60 & $2008-2009$ & 88 & SMPS & $9-520$ \\
\hline 26 & Harwell, UK & HRW & rural & $51^{\circ} 34^{\prime} \mathrm{N}, 1^{\circ} 19^{\prime} \mathrm{W}$ & 60 & 2006 & 86 & SMPS & $12-440$ \\
\hline 27 & Egbert, Canada & EGB & rural & $44^{\circ} 14^{\prime} \mathrm{N}, 79^{\circ} 47^{\prime} \mathrm{W}$ & 251 & 2007-2008 & 93 & SMPS & $10-400$ \\
\hline 28 & Southern Great Plains, US & SGP & rural & $36^{\circ} 36^{\prime} \mathrm{N}, 97^{\circ} 29^{\prime} \mathrm{W}$ & 300 & 2011-2014 & 91 & DMPS & $12-740$ \\
\hline 29 & Botsalano, South Africa & BOT & rural & $25^{\circ} 32^{\prime} \mathrm{S}, 27^{\circ} 75^{\prime} \mathrm{E}$ & 1400 & $2006-2008$ & 80 & DMPS & $11-840$ \\
\hline 30 & Welgegund, South Africa & WGD & rural & $26^{\circ} 34^{\prime} \mathrm{S}, 26^{\circ} 56^{\prime} \mathrm{E}$ & 1480 & $2010-2011$ & 97 & DMPS & $11-840$ \\
\hline 31 & Marikana, South Africa & MAR & urban & $25^{\circ} 42^{\prime} \mathrm{S}, 27^{\circ} 29^{\prime} \mathrm{E}$ & 1170 & $2008-2010$ & 84 & DMPS & $11-840$ \\
\hline 32 & Helsinki, Finland & HEL & urban & $60^{\circ} 12^{\prime} \mathrm{N}, 24^{\circ} 58^{\prime} \mathrm{E}$ & 26 & $2005-2016$ & 96 & DMPS & $3-1000$ \\
\hline 33 & Beijing, China & BEI & urban & $40^{\circ} 0^{\prime} \mathrm{N}, 116^{\circ} 19^{\prime} \mathrm{E}$ & 50 & 2004 & 61 & DMPS & $3-1000$ \\
\hline 34 & Nanjing, China & NAN & urban & $32^{\circ} 7^{\prime} \mathrm{N}, 118^{\circ} 57^{\prime} \mathrm{E}$ & 25 & 2011-2013 & 88 & DMPS & $6-800$ \\
\hline 35 & Budapest, Hungary & BUD & urban & $47^{\circ} 29^{\prime} \mathrm{N}, 19^{\circ} 4^{\prime} \mathrm{E}$ & 115 & $2008-2013$ & 95 & DMPS & $6-1000$ \\
\hline 36 & São Paulo, Brazil & SPL & urban & $23^{\circ} 34^{\prime} \mathrm{S}, 46^{\circ} 44^{\prime} \mathrm{W}$ & 750 & $2010-2011$ & 85 & DMPS & $6-800$ \\
\hline
\end{tabular}

\section{Description of the data and data analysis methods}

Data of aerosol number concentration size distributions was obtained from the EBAS (http://ebas.nilu.no/ (last access: 15 August 2017) and ARM (http://www.archive.arm. gov/discovery/ (last access: 13 June 2017)) databases and from several research groups running long-term atmospheric aerosol measurements. Mobility-based particle spectrometers (differential mobility particle sizer, DMPS; scanning mobility particle sizer, SMPS) typically have lower detection limits varying between 3 and $10 \mathrm{~nm}$ in particle diameter. In order to have comparable results among different sites, a common size range of $10-25 \mathrm{~nm}$ was used for nucleationmode particles in this study.

As part of the data analysis of this study, all the data were visually examined. Time periods when there was sus- picion of instrument malfunction or other effects affecting the quality of the data were left out of the subsequent analysis. It should be noted, however, that the different measurement setups used at different measurement sites (and possibly changes in the measurement setups) could introduce biases among the data sets from different measurement sites. In the literature, there are a few guidelines for ambient aerosol size-distribution measurements and quality assurance procedures (e.g., Wiedensohler et al., 2012, 2017), but not all of the measurement sites follow these guidelines.

Altogether, we identified 36 measurement sites worldwide, for which particle number size distributions have been measured for at least 1 year (either continuously or during separate campaigns covering the full annual cycle). These sites were divided into five groups based on their general environmental characteristics (Table 1, Fig. 1), ranging from 


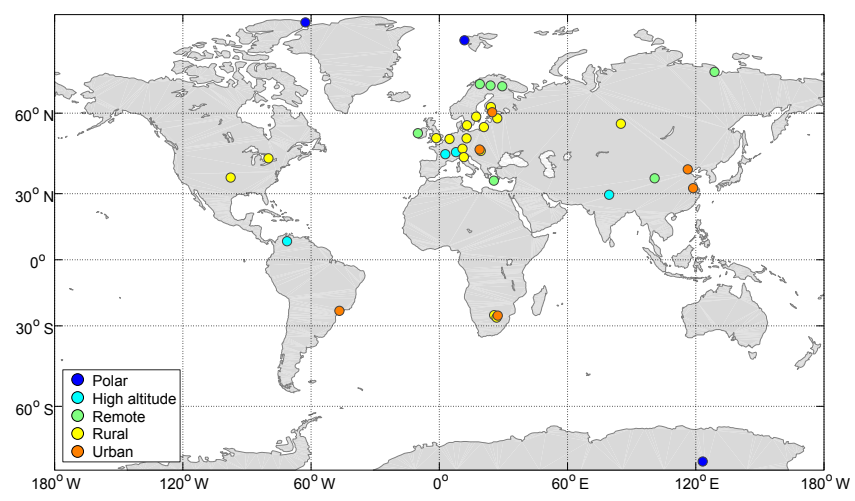

Figure 1. Geographical coverage of the measurement sites offering long-term (at least 1 full year) aerosol number size distribution in the submicron size range. The color of the points refers to the grouping of the sites in Table 1 according to their environment type.

polar and other remote areas with low anthropogenic influence to heavily polluted megacities. While most of the sites included in this study are located in Europe, we have at least two measurement sites from every other continent except Antarctica (only one site) and Australia (no sites). The measurement period lengths range from 1 year at two sites to just over 20 years in the Finnish boreal forest site. Most of the sites had data available for 5-10 years (Table 1).

Concerning the global spatial representativeness of the data sets analyzed in this study, it should be kept in mind that we have considered only measurements from continental areas that cover $29 \%$ of the Earth's surface, the rest being the oceans. Although the emissions of nucleation precursors and condensing vapors from the sea are much smaller than from the land vegetation (Carpenter et al., 2012), the larger overall surface area that they represent and the subsequent impacts on cloud cover may have a significant influence on global climate. However, currently there is no evidence in the published literature from available measurements that NPF over the ocean is a common phenomenon compared to continental environments. Thus, as a future challenge, it would be very important to obtain similar long-term observations from at least a few locations over the Atlantic, Pacific, and Arctic oceans.

\subsection{Description of the measurement sites}

Here we present a very short summary of the 36 sites included in this study. For more detailed information about each site, including their infrastructure, measurement program, and environmental characteristics, we refer to the publications cited below.

\subsubsection{Polar sites}

The Zeppelin Observatory (ZPL) is located on top of Mt. Zeppelin, Svalbard $\left(78^{\circ} 56^{\prime} \mathrm{N}, 11^{\circ} 53^{\prime} \mathrm{E}, 474 \mathrm{~m}\right.$ above sea

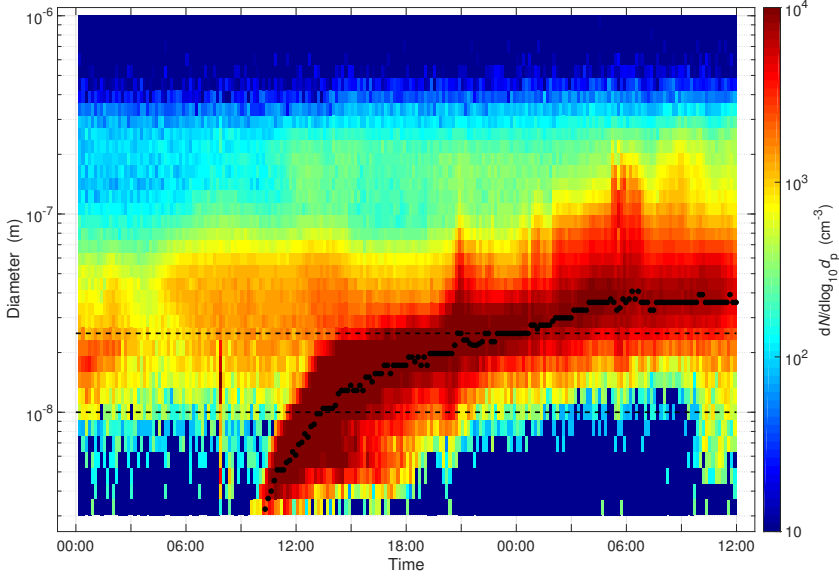

Figure 2. An example of a new particle formation event observed in Hyytiälä, Finland, 15-16 March 2011, illustrating the continuous growth of the newly formed aerosol particles for about $25 \mathrm{~h}$. The geometric mean size of the fitted lognormal size distributions is shown with black dots, and the black dashed lines show the $10-25 \mathrm{~nm}$ size range that is used for calculating the formation rate $J_{\text {nuc }}$ and growth rate $\mathrm{GR}_{\text {nuc }}$.

level, a.s.1.), and is situated just outside the small community of Ny-^̊lesund. It is part of the ACTRIS, GAW, and ICOS programs. The station is mostly unaffected by local sources and is considered to be within the boundary layer most of the time. The station represents remote Arctic conditions and offers a unique possibility to study the characteristic features of Arctic atmospheric trace constituents such as trace gases and aerosols (Tunved et al., 2013).

The Dome-C site (DMC) is located at the East Antarctica plateau at the Italian-French Concordia station, $1100 \mathrm{~km}$ away from the coast $\left(75^{\circ} 06^{\prime} \mathrm{S}, 123^{\circ} 23^{\prime} \mathrm{E}, 3200 \mathrm{~m}\right.$ a.s.1.; Järvinen et al., 2013). The station buildings are $1 \mathrm{~km}$ from the sampling site and upwind relative to the prevailing wind direction. The aerosol measurements with respect to the wind direction from the station are excluded from our analysis.

Alert (ALE) of the Canadian Aerosol Baseline Measurement Program is the northernmost atmospheric measurement site in the world, located on the northeastern part of Ellesmere Island in Nunavut $\left(82^{\circ} 28^{\prime} \mathrm{N}, 62^{\circ} 30^{\prime} \mathrm{W}, 75 \mathrm{~m}\right.$ a.s.1.; Leaitch et al., 2013). It is part of the World Meteorological Organization's Global Atmosphere Watch (GAW) network. Alert is characterized by clean Arctic air during summer and long-range transport of more polluted air in southerly air masses primarily from Europe and Asia during winter and spring.

\subsubsection{High-altitude sites}

Jungfraujoch (JFJ) is a background site located in the Alps on a mountain ridge away from major pollution sources, and belongs to the GAW network $\left(46^{\circ} 33^{\prime} \mathrm{N}, 7^{\circ} 59^{\prime} \mathrm{E}, 3580 \mathrm{~m}\right.$ a.s.l; Boulon et al., 2010; Bianchi et al., 2016; Bukowiecki et al., 

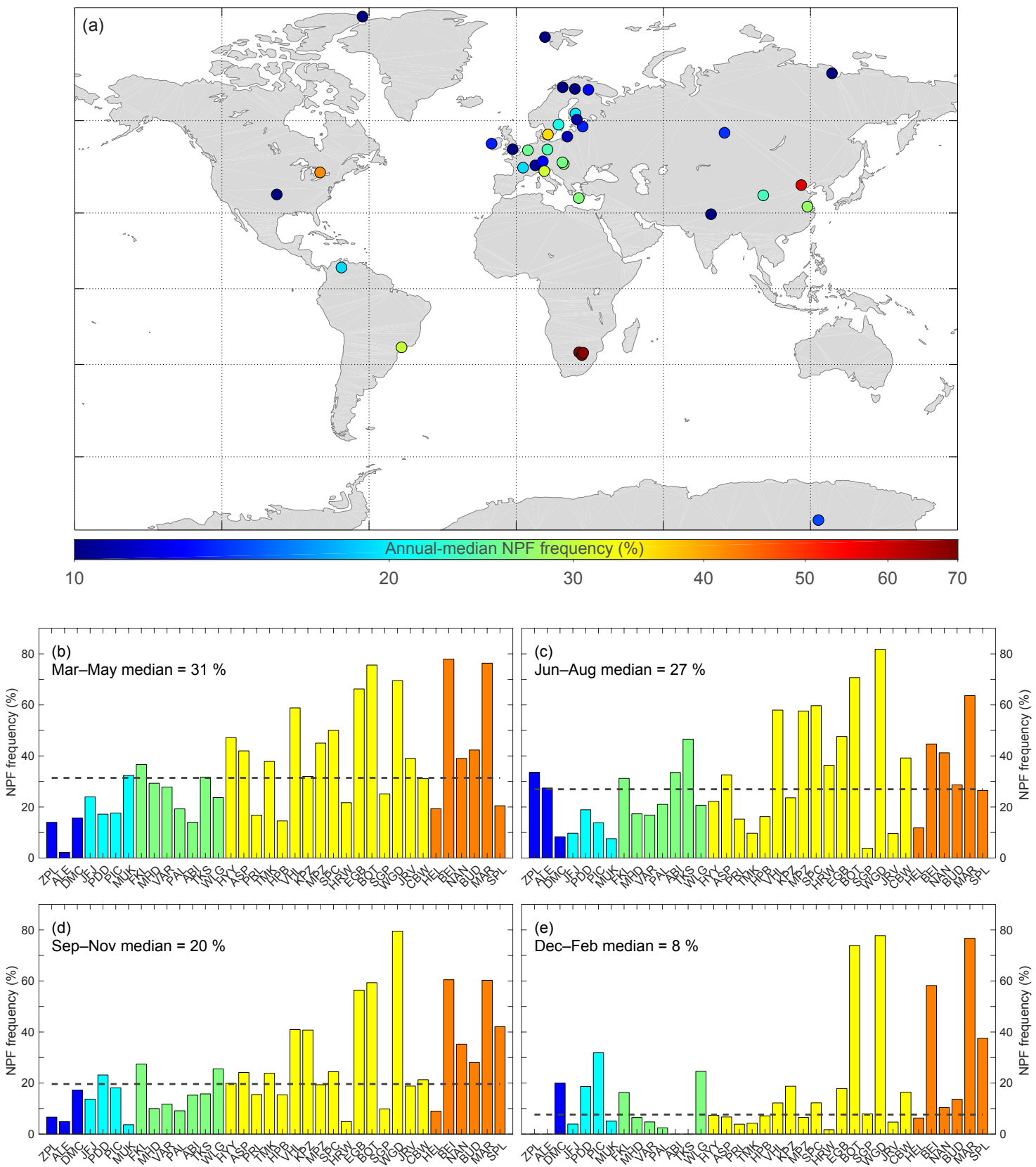

Figure 3. Annual-median (a) and seasonal-median (b-e) frequency of the NPF formation events at the different measurement sites. The dashed lines in panels (b-e) show the median seasonal values, and the color scheme represents the classification of the sites into polar, high-altitude, remote, rural, and urban environments.

2016). It contributes to numerous networks, including GAW, ACTRIS, ICOS, NDACC, and AGAGE. For approximately $40 \%$ of the time the station is inside clouds, and part of the time the station is considered to be in the free troposphere.

The Puy de Dôme GAW research station (PDD; $45^{\circ} 46^{\prime} \mathrm{N}$, $2^{\circ} 57^{\prime} \mathrm{E}$ ) is located in central France, approximately $200 \mathrm{~km}$ from the Atlantic Ocean coast and $150 \mathrm{~km}$ from the Mediterranean Sea. It is on top of a volcano, at $1465 \mathrm{~m}$ a.s.l., and may be located either in the continental boundary layer or the free troposphere (Venzac et al., 2009; Boulon et al., 2011). It is representative of a large regional fingerprint and is classified as a background regional site (Asmi et al., 2011).

Pico Espejo (PIC; $8^{\circ} 30^{\prime} \mathrm{N}, 71^{\circ} 6^{\prime} \mathrm{W}$ ) is a tropical highaltitude station located at $7^{\circ} \mathrm{N}$ on top of the Venezuelan Andes at an altitude of $4775 \mathrm{~m}$ a.s.l. (Schmeissner et al., 2011). It is representative of the tropical free troposphere and for studies on the influence of orographic lifting of boundary layer air to the free troposphere. 

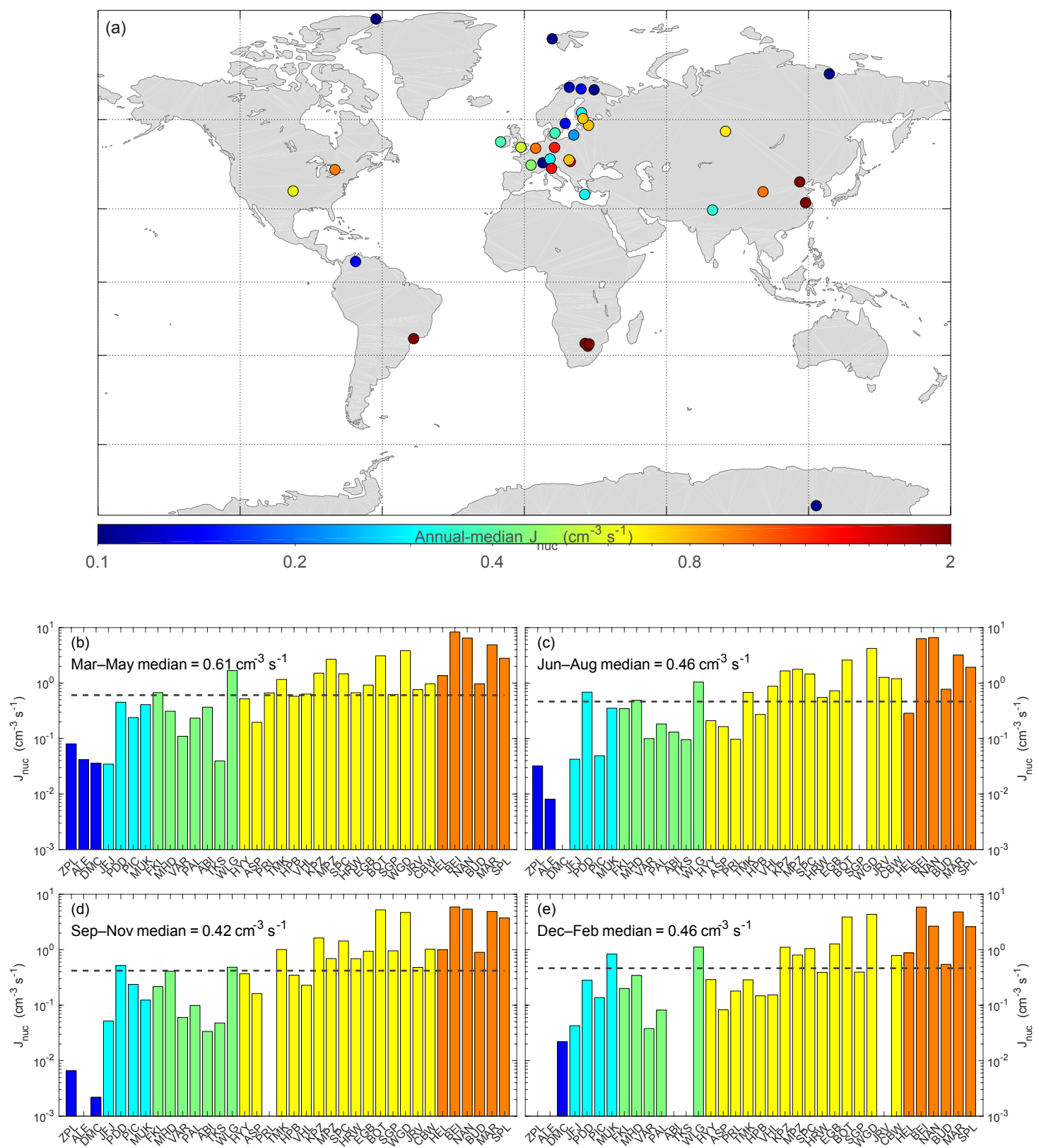

Figure 4. Annual-median (a) and seasonal-median (b-e) particle formation rate at the different measurement sites. The dashed lines in panels (b-e) show the median seasonal values, and the color scheme represents the classification of the sites into polar, high-altitude, remote, rural, and urban environments.

The Mukteshwar station (MUK; $29^{\circ} 26^{\prime} \mathrm{N}, 79^{\circ} 37^{\prime} \mathrm{E}$, $2180 \mathrm{~m}$ a.s.l.) is located in northeast India about $250 \mathrm{~km}$ from Delhi at the foothills of the central Himalayan mountains (Hyvärinen et al., 2009; Neitola et al., 2011). The area surrounding the site consists of low mountains (peaks at 1500 $2500 \mathrm{~m}$ a.s.1.) between the plains (100-200 $\mathrm{m}$ a.s.l.) and the Himalayas (peaks at $6000-8000 \mathrm{~m}$ a.s.l). The site is influenced by regional polluted air that has been transported from the plains below.

\subsubsection{Remote sites}

The Finokalia station (FKL; $35.3^{\circ} \mathrm{N}, 25.7^{\circ} \mathrm{E} ; 235 \mathrm{~m}$ a.s.l) is located at the top of a hill over the coastline, in the northeastern part of the island of Crete (Greece). The station is little influenced by local anthropogenic sources and it is considered representative for the background marine conditions of the eastern Mediterranean (Mihalopoulos et al., 1997).

Mace Head (MHD; 53.2 $\mathrm{N}, 9.8^{\circ} \mathrm{W} ; 10 \mathrm{~m}$ a.s.l) is a coastal station on the west coast of Ireland and receives clean ma- 
rine air masses from the northeastern Atlantic approximately $50 \%$ of the time. It serves as an excellent background marine aerosol characterization station as well as a polluted European outflow station. Mace Head is a WMO-GAW global station and an EMEP supersite and contributes to the ACTRIS and AGAGE networks. A full description can be found in O'Connor et al. (2008) and O'Dowd et al. (2014).

The Värriö (VÄR) SMEAR I (Station for Measuring Forest Ecosystem-Atmosphere Relations) measurement site is located on top of the Kotovaara fjeld, surrounded by a 60year-old Scots pine forest $\left(67^{\circ} 45^{\prime} \mathrm{N}, 29^{\circ} 36^{\prime} \mathrm{E}, 390 \mathrm{~m}\right.$ a.s.l). The station is close to the Finnish-Russian border and is at times impacted by the air pollution coming from the Kola Peninsula mining and industrial areas $200-300 \mathrm{~km}$ northeast and east from the station (Kyrö et al., 2014).

The Pallas Atmosphere-Ecosystem Supersite station (PAL; 67 $58^{\prime} \mathrm{N}, 24^{\circ} 07^{\prime} \mathrm{E} ; 565 \mathrm{~m}$ a.s.1.) is located in northern Finland. The main station building is within a natural park area, on top of a hill above the tree line (Hatakka et al., 2003; Lohila et al., 2015). It is surrounded by vegetation of low vascular plants, moss, and lichen. The environment is representative of remote sub-Arctic and boreal forests. The station contributes to numerous European and global research programs, such as GAW, ICOS, ACTRIS, and EMEP.

The Abisko measurement station (ABI) is located in a discontinuous permafrost zone at the Stordalen mire, approximately $14 \mathrm{~km}$ east of the small village of Abisko in northern Sweden $\left(68.35^{\circ} \mathrm{N}, 19.05^{\circ} \mathrm{E}, 380 \mathrm{~m}\right.$ a.s.l). The area is characterized by subarctic birch forest, wetlands, and tundra ecosystems as well as a low population density (Svenningsson et al., 2008).

The Tiksi Hydrometeorological Observatory (TKS; $\left.71^{\circ} 36^{\prime} \mathrm{N}, 128^{\circ} 53^{\prime} \mathrm{E}, 10 \mathrm{ma.s.1}\right)$ is located in northern Siberia on the coast of the Laptev Sea (Uttal et al., 2013; Asmi et al., 2016). The station is about $5 \mathrm{~km}$ southwest from the city of Tiksi and about $500 \mathrm{~m}$ from the sea. The site is surrounded by low tundra vegetation with no trees.

The Waliguan Baseline Observatory (WLG; $36^{\circ} 17^{\prime} \mathrm{N}$, $100^{\circ} 54^{\prime} \mathrm{E}, 3816 \mathrm{~m}$ a.s.l; Kivekäs et al., 2009) is part of the GAW network, situated on top of Mt. Waliguan, located at the edge of the northeastern part of the Qinghai-Xizang (Tibet) Plateau in a remote region of western China. Even though the station is located at a mountain peak and at a very high altitude, a clear planetary boundary layer-free troposphere daily cycle in aerosol properties is not observed there. Therefore the Waliguan site is more representative of remote conditions.

\subsubsection{Rural sites}

The Hyytiälä measurement site (HYY) is at the SMEAR II station located in southern Finland $60 \mathrm{~km}$ northeast from Tampere $\left(61^{\circ} 51^{\prime} \mathrm{N}, 24^{\circ} 17^{\prime} \mathrm{E}, 181 \mathrm{~m}\right.$ a.s.l.; Hari and Kulmala, 2005). The station is equipped with extensive facilities to measure forest ecosystem-atmosphere interactions continu- ously and comprehensively. A rather homogeneous coniferous boreal forest surrounds this rural continental station.

Aspvreten (ASP) is located ca. $2 \mathrm{~km}$ inland from the Baltic Sea $\left(58.8^{\circ} \mathrm{N}, 17.4^{\circ} \mathrm{E}, 25 \mathrm{~m}\right.$ a.s.1.) and some $80 \mathrm{~km}$ south of Stockholm. The surroundings are dominated by deciduous and coniferous forest, and the station is relatively unaffected by local anthropogenic activities (Tunved et al., 2004).

The Preila station (PRL; 55.4 $4^{\circ}, 21.0^{\circ} \mathrm{E}, 10 \mathrm{~m}$ a.s.1.) is located in the western part of Lithuania on the shore of the Baltic Sea, on the Curonian Spit. The Curonian Spit is a narrow sandy strip peninsula ( 0.4 to $4.0 \mathrm{~km}$ in width), which separates the Baltic Sea from the Curonian Lagoon. Its width is approximately $2 \mathrm{~km}$ at the Preila site. The dunes, up to $50 \mathrm{~m}$ in height, as well as natural forests in low-lying lands predominate in the region. The marine, submarine climate is specific to this terrain. This monitoring site was selected according to strict criteria designed to avoid undue influence from point sources, area sources, and local activities (Pauraite et al., 2015).

The Tomsk Fonovaya Observatory (TMK) for monitoring atmospheric composition is located in the southern taiga belt of West Siberia $\left(56^{\circ} 25^{\prime} \mathrm{N}, 84^{\circ} 4^{\prime} \mathrm{E}, 145 \mathrm{~m}\right.$ a.s.l.; Matvienko et al., 2015). It is representative of a background boreal environment and is situated on the bank of the river Ob, $60 \mathrm{~km}$ west of the city of Tomsk. In close proximity to the site there is a mixed forest and large areas surrounding the site are covered mainly with coniferous trees.

The Järvselja SMEAR Estonia station (JRV) is located in the Järvselja Experimental Forest in the southeastern part of Estonia, about $35 \mathrm{~km}$ southeast of Tartu $\left(58^{\circ} 16^{\prime} \mathrm{N}, 27^{\circ} 16^{\prime} \mathrm{E}\right.$, $36 \mathrm{~m}$ a.s.1.; Noe et al., 2015; Vana et al., 2016). The site, located in the vicinity of Lake Peipus, is surrounded by mixed forest in the hemi-boreal forest zone. There are no large villages or cities near the site.

Hohenpeissenberg (HPB) is a GAW station located $60 \mathrm{~km}$ south of Munich on a mountain elevated $300 \mathrm{~m}$ above the surrounding countryside in southern Germany $\left(47^{\circ} 48^{\prime} \mathrm{N}\right.$, $11^{\circ} 1^{\prime} \mathrm{E}, 988 \mathrm{~m}$ a.s.1.; Birmili et al., 2003). There are no major anthropogenic pollution sources nearby the station.

Vavihill station (VHL) is located at the southernmost part of Sweden $\left(56^{\circ} 1^{\prime} \mathrm{N}, 13^{\circ} 9^{\prime} \mathrm{E}, 172 \mathrm{~m}\right.$ a.s.l.; Kristensson et al., 2008). The station is away from local air pollution sources but still within $40-45 \mathrm{~km}$ from the densely populated cities of Malmö and Copenhagen. Air masses arriving at the station from the northwest to northeast are typically very clean.

The K-puszta site (KPZ) is located in a rural area in Hungary, $15 \mathrm{~km}$ away from the nearest town of Kecskemét and $71 \mathrm{~km}$ from Budapest $\left(46^{\circ} 58^{\prime} \mathrm{N}, 19^{\circ} 33^{\prime} \mathrm{E}, 125 \mathrm{~m}\right.$ a.s.1.; Salma et al., 2016a). The station is in a clearing within a mixed forest of coniferous and deciduous trees.

Melpitz (MPZ) is located $40 \mathrm{~km}$ northeast of Leipzig and surrounded by flat and seminatural grasslands without any obstacles in all directions $\left(51^{\circ} 32^{\prime} \mathrm{N}, 12^{\circ} 54^{\prime} \mathrm{E}, 87 \mathrm{~m}\right.$ a.s.1.; Hamed et al., 2010). Agricultural pastures and wooded areas make up the wider regional surroundings of this regional 
background site. It is representative of the central European background. Measurements at the Melpitz site are part of ACTRIS, GUAN, and GAW programs.

The San Pietro Capofiume station (SPC) is located in the Po Valley, Italy, approximately $30 \mathrm{~km}$ from Bologna $\left(44^{\circ} 39^{\prime} \mathrm{N}, 11^{\circ} 37^{\prime} \mathrm{E}, 11 \mathrm{~m}\right.$ a.s.l.; Hamed et al., 2007). The Po Valley area is an industrial and agricultural area with a high population density. The station itself is in rural area surrounded by the Adriatic Sea on the east and densely populated areas on its southern, western, and northern sides.

The Cabauw (CBW) Experimental Site for Atmospheric Research (CESAR) is located in the central Netherlands close to the North Sea $\left(51^{\circ} 18^{\prime} \mathrm{N}, 4^{\circ} 55^{\prime} \mathrm{E}, 60 \mathrm{~m}\right.$ a.s.l.; Russchenberg et al., 2005). The CESAR observatory is located at a rural site with flat meadows in an otherwise densely populated area. It is representative for different environments depending on the wind directions.

The Harwell measurement site (HRW) is located in a rural environment in southern England $\left(51^{\circ} 34^{\prime} \mathrm{N}, 1^{\circ} 19^{\prime} \mathrm{W}\right.$, $60 \mathrm{~m}$ a.s.l.; Charron et al., 2007). It is representative of the rural background in one of the more densely populated areas within western Europe.

The Egbert site (EGB) of Environment and Climate Change Canada Centre for Atmospheric Research Experiments is located in rural Ontario surrounded by agricultural areas and small towns $\left(44^{\circ} 14^{\prime} \mathrm{N}, 79^{\circ} 47^{\prime} \mathrm{W}, 251 \mathrm{~m}\right.$ a.s.l; Rupakheti et al., 2005; Slowik et al., 2010; Pierce et al., 2014). With extensive forest to the north and the major urban center of Toronto about $80 \mathrm{~km}$ to the south, the site experiences many different types of aerosol depending on the wind direction.

The Southern Great Plains (SGP) central facility site of the US Department of Energy Atmospheric Radiation Measurement (ARM) program is located near Lamont, Oklahoma $\left(36^{\circ} 36^{\prime} \mathrm{N}, 97^{\circ} 29^{\prime} \mathrm{W}, 300 \mathrm{~m}\right.$ a.s.l.; Parworth et al., 2015). It is representative of the Great Plains region, and the surrounding areas have various anthropogenic activities including agriculture, animal husbandry, and oil and gas extraction.

Botsalano (BOT) is located in South Africa, $200 \mathrm{~km}$ westnorthwest of Johannesburg in a game reserve in a savannah environment $\left(25^{\circ} 32^{\prime} \mathrm{S}, 27^{\circ} 75^{\prime} \mathrm{E}, 1400 \mathrm{~m}\right.$ a.s.l.; Laakso et al., 2008; Vakkari et al., 2011). Although there are no local anthropogenic sources, Botsalano is impacted by aged emissions from industrialized Highveld and is thus considered a semi-clean location.

Welgegund (WGD) is located in central South Africa within the grassland biome on a private farm, with no local sources ( $26^{\circ} 34^{\prime} \mathrm{S}, 26^{\circ} 56^{\prime} \mathrm{E}, 1480 \mathrm{~m}$ a.s.1.; Tiitta et al., 2014; Jaars et al., 2016). The site is impacted by the emissions from various strongly anthropogenically impacted source regions (e.g., the Bushveld Complex $100 \mathrm{~km}$ to the north and northeast, the Johannesburg-Pretoria megacity and surrounding industries $100 \mathrm{~km}$ to the north and east, and the Highveld and Vaal Triangle areas $100 \mathrm{~km}$ to the east and southeast). It also has a wide clean sector to the west. Welgegund is representa- tive of the mosaic of grassland, cropland, and anthropogenic activities in the interior of southern Africa.

\subsubsection{Urban and anthropogenically influenced sites}

Marikana (MAR) is located in the middle of a platinum group of metal refineries near the city of Rustenburg, South Africa $\left(25^{\circ} 42^{\prime} \mathrm{S}, 27^{\circ} 29^{\prime} \mathrm{E}, 1170 \mathrm{~m}\right.$ a.s.l.; Venter et al., 2012, 2016). In addition to the industrial $\mathrm{SO}_{2}$ emissions, the site is heavily impacted by domestic heating and cooking emissions in nearby low-income residential areas.

The Helsinki measurement site (HEL) is the SMEAR III station in the University of Helsinki campus area $\left(60^{\circ} 12^{\prime} \mathrm{N}\right.$, $24^{\circ} 58^{\prime} \mathrm{E}, 26 \mathrm{~m}$ a.s.1.; Hussein et al., 2008). The site is located next to a busy road on a hill elevated by $20 \mathrm{~m}$ from the surrounding area.

The Beijing site (BEI) is located on a rooftop in the campus area of Peking University in the northwestern part of Beijing $\left(40^{\circ} 00^{\prime} \mathrm{N}, 116^{\circ} 19^{\prime} \mathrm{E}, 50 \mathrm{~m}\right.$ a.s.l.; Wu et al., 2007), as the Peking University Urban Atmosphere Environment Monitoring Station (PKUERS). A major road is located $500 \mathrm{~m}$ from the site, but there are no significant stationary air pollution sources nearby.

The Nanjing SORPES station (NAN) is located about $20 \mathrm{~km}$ northeast of downtown Nanjing, China $\left(32^{\circ} 7^{\prime} \mathrm{N}\right.$, $118^{\circ} 57^{\prime}$ E, $25 \mathrm{~m}$ a.s.l.; Qi et al., 2015; Ding et al., 2016). With only few local sources within its $2-3 \mathrm{~km}$ surroundings and generally upwind of the city, it can be considered to be a regional background site in the urbanized Yangtze River Delta region of eastern China.

The measurements in Budapest (BUD) were conducted at two nearby sites: at the Budapest Platform for Aerosol Research and Training in the city center on the bank of the Danube $\left(47^{\circ} 29^{\prime} \mathrm{N}, 19^{\circ} 4^{\prime} \mathrm{E}, 115 \mathrm{~m}\right.$ a.s.l.; Salma et al., 2016b) and at the Konkoly Observatory in a background area near the city $\left(47^{\circ} 30^{\prime} \mathrm{N}, 18^{\circ} 58^{\prime} \mathrm{E}, 478 \mathrm{~m}\right.$ a.s.l). The first of the sites is representative of well-mixed urban air, and the second site is located in a wooded area (Németh and Salma, 2014).

The São Paulo measurement site (SPL) is located in the campus area of the University of São Paulo $10 \mathrm{~km}$ from the city center $\left(23^{\circ} 34^{\prime} \mathrm{S}, 46^{\circ} 44^{\prime} \mathrm{W}, 750 \mathrm{~m}\right.$ a.s.l.; Backman et al., 2012). The São Paulo metropolitan area is the world's seventh largest city, and the measurement site is representative of the anthropogenic pollution of the city area with no strong local sources in the vicinity of the site.

\subsection{Data analysis methods}

All data sets were analyzed with the procedure following the particle number size distribution data analysis guidelines presented by Kulmala et al. (2012). This was carried out in order to obtain a data set as coherent as possible. We classified every measurement day at each measurement site into one of the following three categories: NPF event day, non-event day, or undefined day (those days that could not be unam- 
biguously classified into NPF or non-NPF days). We used the criteria originally introduced by Dal Maso et al. (2005), in which the class I event days are those during which the formation and subsequent growth of the nucleation-mode particles is clearly distinguishable in the number size-distribution data for at least a few hours (Fig. 2). Class II event days are those during which there are evident inhomogeneities in the sampled air masses, causing fluctuations in aerosol processes and in the observed particle size distributions, but the regional NPF is still clearly observable. For a more detailed discussion of the analysis procedure, see Kulmala et al. (2012).

In order to quantify the intensity of individual NPF events, we calculated the formation rate $J_{\text {nuc }}$ of nucleation-mode particles (10-25 nm in diameter) based on the following balance equation (Kulmala et al., 2012):

$J_{\mathrm{nuc}}=\frac{\mathrm{d} N_{\mathrm{nuc}}}{\mathrm{d} t}+\operatorname{CoagS} \cdot N_{\mathrm{nuc}}+\frac{\mathrm{GR}}{\Delta d_{\mathrm{p}, \mathrm{nuc}}} \cdot N_{\mathrm{nuc}}$.

Here $N_{\text {nuc }}$ is the total number concentration of $10-25 \mathrm{~nm}$ nucleation-mode particles, CoagS is the coagulation sink for the nucleation-mode particles (calculated using the particle diameter of $15 \mathrm{~nm}$ as the geometric mean of the $10-25 \mathrm{~nm}$ size range) due to the preexisting larger particles, GR is the observed GR of particles through the $10-25 \mathrm{~nm}$ size range, and $\Delta d_{\mathrm{p} \text {,nuc }}$ is the width of the $10-25 \mathrm{~nm}$ size range. The GR was calculated by first fitting lognormal modes to the measured particle number size-distribution data using an automated algorithm developed by Hussein et al. (2008), and then following the time evolution of the geometric mean of the nucleation mode. A linear function was fitted to the data points of the nucleation-mode size as a function of time, and the slope of the fitted line gave the GR. The coagulation sinks were calculated based on the dry size distribution. The relative-humidity-dependent hygroscopic growth of the particles was not taken into account in our analyses since this might differ among sites according to the particles' chemical composition and there are only a few parameterizations for the hygroscopic growth available in the literature (Kulmala et al., 2012).

\section{Results and discussion}

Below we discuss three quantities that characterize atmospheric NPF events: the observed frequency of regional NPF events at individual measurement sites, the average formation rate of $10-25 \mathrm{~nm}$ particles $\left(J_{\text {nuc }}\right)$ during each event, and the corresponding GR of $10-25 \mathrm{~nm}$ particles. We will investigate both the overall behavior of these three quantities and their seasonal variability. Rather than looking at individual measurement sites, we will concentrate our analysis on five groups of the sites that represent different environmental regimes: polar areas, high-altitude locations, remote areas, rural areas, and urban areas. The individual values of the seasonal site-specific medians of the NPF event frequencies and nucleation-mode particle formation and GRs are given in Table 2. Note that the NPF frequency is the fraction of all class I and II NPF days from all the days with aerosol size-distribution data, but the particle formation and GRs are calculated only for the class I NPF events.

\subsection{General characteristics of regional NPF and its seasonal cycle}

Regional NPF events were observed at all the 36 sites throughout the year (Fig. 3), with events being most frequent at the three sites in southern Africa (MAR, WGD, BOT) and least frequent at the two sites at high northern latitudes (ZPL, ALE). It should be noted that although at all the sites we selected NPF events that exhibited formation and continuous growth of nucleation-mode particles during several hours (i.e., fulfilling our criteria of regional NPF), the local conditions of each individual measurement site do influence the apparent NPF characteristics. For example, at high-altitude mountainous sites the orographic lifting of air parcels during the day can affect the conditions favorable to NPF. Such NPF events might show a temporal evolution of the particle number size distribution that is different from NPF events at locations with more homogeneous topography (Venzac et al., 2009; Tröstl et al., 2016). Thus, when comparing the results presented in this study to global modeling results, for example, the regional representativeness should be kept in mind.

The overall frequency of NPF did not show any consistent differences, or patterns, among the high-altitude, remote, rural, and urban sites. There were, however, large site-to-site differences in this frequency. Seasonally, the NPF frequency was typically the highest during March-May, the median value being equal to $31 \%$ among the seasonal-median values at each site. Since many of the Northern Hemisphere sites had very low NPF event frequencies during the local winter, the median value of this frequency was the lowest $(8 \%)$ during the December-February period. The vast majority of the sites (30 out of 36) clearly showed more NPF events during the local spring and summer compared with the local winter, as has also been reported in many previous studies in the literature (see, e.g., Kulmala et al., 2012, and references therein).

The observed formation rates of $10-25 \mathrm{~nm}$ particles increased, on average, with an increasing degree of anthropogenic influence, being 1 to 2 orders of magnitude higher in urban areas compared with most of the sites in remote and polar environments (Fig. 4) This indicates the importance of anthropogenic vapors (such as sulfur dioxide, ammonia, amines) to NPF. Interestingly, the three high-altitude sites (JFJ, PDD, PIC) showed seasonal-median values of $J_{\text {nuc }}$ that were comparable to those at remote lower-altitude areas. There are a few studies in which NPF has been studied in detail over different parts of the atmospheric column, and several mechanisms favoring or inhibiting NPF at differ- 
Table 2. Site-specific seasonal-median values of NPF event frequencies (fraction of class I and II NPF days from all the days with measurement data) and nucleation-mode particle formation and growth rates. A value is not given (indicated by -) if there were fewer than three quantifiable NPF events in any given season.

\begin{tabular}{|c|c|c|c|c|c|c|c|c|c|c|c|c|}
\hline \multirow[b]{2}{*}{ Site } & \multicolumn{4}{|c|}{ Fraction of NPF days (\%) } & \multicolumn{4}{|c|}{ Formation rate $\left(\mathrm{cm}^{-3} \mathrm{~s}^{-1}\right)$} & \multicolumn{4}{|c|}{ Growth rate $\left(\mathrm{nm} \mathrm{h}^{-1}\right)$} \\
\hline & Mar-May & Jun-Aug & Sep-Nov & Dec-Feb & Mar-May & Jun-Aug & Sep-Nov & Dec-Feb & Mar-May & Jun-Aug & Sep-Nov & Dec-Feb \\
\hline ZPL & 14.0 & 33.6 & 6.6 & 0.0 & 0.080 & 0.032 & 0.0066 & - & 1.4 & 1.2 & 1.6 & - \\
\hline DMC & 15.7 & 8.3 & 17.2 & 20.0 & 0.036 & - & 0.0022 & 0.022 & 1.3 & - & 0.5 & 2.5 \\
\hline ALE & 2.2 & 27.4 & 4.9 & 0.0 & 0.042 & 0.0081 & - & - & 0.8 & 1.1 & - & - \\
\hline JFJ & 23.9 & 9.7 & 13.7 & 3.9 & 0.035 & 0.042 & 0.052 & 0.043 & 2.7 & 3.1 & 1.5 & 3.0 \\
\hline PDD & 17.2 & 18.9 & 23.2 & 18.7 & 0.45 & 0.68 & 0.52 & 0.28 & 3.2 & 6.2 & 5.0 & 5.7 \\
\hline PIC & 17.6 & 13.8 & 18.1 & 31.9 & 0.24 & 0.049 & 0.24 & 0.14 & 2.7 & 3.0 & 4.0 & 4.0 \\
\hline MUK & 32.3 & 7.6 & 3.7 & 5.1 & 0.41 & 0.35 & 0.12 & 0.84 & 2.7 & 4.1 & 3.1 & 6.0 \\
\hline WLG & 23.7 & 20.7 & 25.5 & 24.6 & 1.7 & 1.0 & 0.48 & 1.1 & 2.4 & 5.1 & 1.4 & 2.2 \\
\hline FKL & 36.6 & 31.2 & 27.4 & 16.3 & 0.67 & 0.35 & 0.22 & 0.20 & 3.9 & 6.4 & 4.4 & 2.1 \\
\hline MHD & 29.3 & 17.3 & 10.0 & 6.5 & 0.31 & 0.49 & 0.41 & 0.35 & 2.1 & 2.8 & 2.7 & 2.3 \\
\hline VÄR & 27.8 & 16.8 & 11.8 & 4.8 & 0.11 & 0.10 & 0.060 & 0.038 & 1.9 & 3.9 & 2.4 & 2.2 \\
\hline PAL & 19.3 & 21.0 & 9.1 & 2.5 & 0.23 & 0.18 & 0.099 & 0.082 & 1.6 & 3.6 & 2.0 & 1.6 \\
\hline ABI & 14.0 & 33.5 & 15.3 & 0.0 & 0.37 & 0.13 & 0.034 & - & 2.2 & 4.4 & 0.8 & - \\
\hline TKS & 31.7 & 46.6 & 15.8 & 0.0 & 0.040 & 0.096 & 0.048 & - & 2.7 & 3.4 & 2.3 & - \\
\hline HYY & 47.2 & 22.2 & 19.9 & 7.4 & 0.52 & 0.21 & 0.37 & 0.29 & 2.2 & 4.6 & 2.8 & 1.9 \\
\hline ASP & 42.0 & 32.6 & 24.2 & 6.7 & 0.20 & 0.16 & 0.16 & 0.083 & 2.2 & 3.0 & 2.5 & 2.7 \\
\hline PRL & 16.8 & 15.3 & 15.5 & 3.9 & 0.67 & 0.097 & - & 0.18 & 1.7 & 1.4 & - & 3.3 \\
\hline TMK & 37.8 & 9.7 & 23.8 & 4.3 & 1.2 & 0.68 & 1.0 & 0.29 & 2.6 & 6.7 & 2.3 & 0.8 \\
\hline JRV & 39.1 & 9.6 & 18.8 & 4.7 & 0.76 & 1.3 & 0.48 & - & 1.9 & 7.2 & 2.7 & - \\
\hline HPB & 14.5 & 16.2 & 15.4 & 7.1 & 0.58 & 0.27 & 0.35 & 0.15 & 5.2 & 2.6 & 6.3 & 4.3 \\
\hline VHL & 58.8 & 58.0 & 41.0 & 12.2 & 0.63 & 0.88 & 0.23 & 0.15 & 3.3 & 3.1 & 2.4 & 3.4 \\
\hline KPZ & 32.0 & 23.6 & 40.8 & 18.8 & 1.5 & 1.7 & 1.6 & 1.1 & 3.6 & 4.0 & 3.7 & 3.3 \\
\hline MPZ & 45.0 & 57.6 & 19.3 & 6.5 & 2.7 & 1.8 & 0.69 & 0.80 & 2.5 & 2.7 & 2.5 & 2.6 \\
\hline SPC & 50.0 & 59.7 & 24.5 & 12.2 & 1.5 & 1.5 & 1.4 & 1.1 & 4.0 & 4.0 & 3.7 & 3.4 \\
\hline CBW & 31.1 & 39.2 & 21.3 & 16.4 & 0.97 & 1.2 & 1.0 & 0.79 & 3.9 & 4.9 & 3.5 & 2.9 \\
\hline HRW & 21.7 & 36.4 & 4.9 & 1.7 & 0.67 & 0.55 & 0.69 & 0.39 & 2.1 & 2.9 & 2.3 & 1.6 \\
\hline EGB & 66.3 & 47.6 & 56.4 & 17.9 & 0.92 & 0.73 & 0.94 & 1.3 & 6.0 & 6.1 & 5.4 & 9.6 \\
\hline SGP & 25.1 & 3.8 & 9.9 & 7.9 & 0.62 & - & 0.96 & 0.39 & 4.0 & - & 3.4 & 1.5 \\
\hline BOT & 75.6 & 70.7 & 59.3 & 73.9 & 3.1 & 2.6 & 5.3 & 3.9 & 7.5 & 7.2 & 10.9 & 9.9 \\
\hline WGD & 69.5 & 81.8 & 79.5 & 77.8 & 3.9 & 4.2 & 4.7 & 4.4 & 9.2 & 7.3 & 10.7 & 10.7 \\
\hline MAR & 76.4 & 63.6 & 60.3 & 76.7 & 4.9 & 3.2 & 4.9 & 4.8 & 8.1 & 6.1 & 8.5 & 9.7 \\
\hline HEL & 19.3 & 11.8 & 9.0 & 6.3 & 1.4 & 0.29 & 1.0 & 0.88 & 2.0 & 2.1 & 3.4 & 2.1 \\
\hline BEI & 78.0 & 44.7 & 60.5 & 58.2 & 8.4 & 6.3 & 5.9 & 5.9 & 3.3 & 4.6 & 2.0 & 1.6 \\
\hline NAN & 39.0 & 41.2 & 35.2 & 10.4 & 6.5 & 6.6 & 5.4 & 2.7 & 5.1 & 6.4 & 5.2 & 4.2 \\
\hline BUD & 42.3 & 28.7 & 28.0 & 13.6 & 0.97 & 0.78 & 0.9 & 0.55 & 4.6 & 5.1 & 4.5 & 2.9 \\
\hline SPL & 20.5 & 26.5 & 42.1 & 37.5 & 2.8 & 1.9 & 3.8 & 2.6 & 3.7 & 4.2 & 3.4 & 2.1 \\
\hline
\end{tabular}

ent altitudes have been discussed without a clear consensus (Crumeyrolle et al., 2010; Boulon et al., 2011; Rose et al., 2015). The seasonal variability in the particle formation rate was quite modest at most of the sites, and especially so when comparing it with the site-to-site differences in this quantity. The median value of $J_{\text {nuc }}$ among the site-specific median values was between 0.4 and $0.6 \mathrm{~cm}^{-3} \mathrm{~s}^{-1}$ in all seasons. The seasonal variation of $J_{\text {nuc }}$ followed that of the NPF event frequency, except for December-February when NPF event frequency was lowest but $J_{\text {nuc }}$ values were similar to those in June-August.

The observed GRs of $10-25 \mathrm{~nm}$ particles were the lowest at the two northern high-latitude sites (ZPL, ALE; Fig. 5). Somewhat higher values of GR than the ones observed for the northern sites, and with relatively minor site-to-site differences, were generally observed at remote and high-altitude sites. An exception to this pattern was PDD, which had clearly higher values of GR than any other high-altitude site and most of the remote sites. This has been observed to be caused by orographic vertical transport of particles nucleated in the boundary layer (Boulon et al., 2011). The particle GRs tended to be the highest in rural and urban areas, even though large site-to-site differences were evident. The observed season-median values of GR varied from slightly below $1 \mathrm{~nm} \mathrm{~h}^{-1}$ (DMC, spring) up to about $10 \mathrm{~nm} \mathrm{~h}^{-1}$ at several sites (e.g., EGB, BOT, WGD). Two rural stations, Botsalano (BOT) and Welgegund (WGD), and the urban station Marikana (MAR) located in South Africa showed similar seasonal variability in median GR, probably due to emissions of gaseous pollutants from various anthropogenically impacted source regions nearby. For most of the sites (33 out of 36), the season-median values of GR were the highest during the local summer and the lowest during the local winter. As a result, the overall median particle GR was clearly higher during the June-August period $\left(4.0 \mathrm{~nm} \mathrm{~h}^{-1}\right)$ compared with the December-February period 

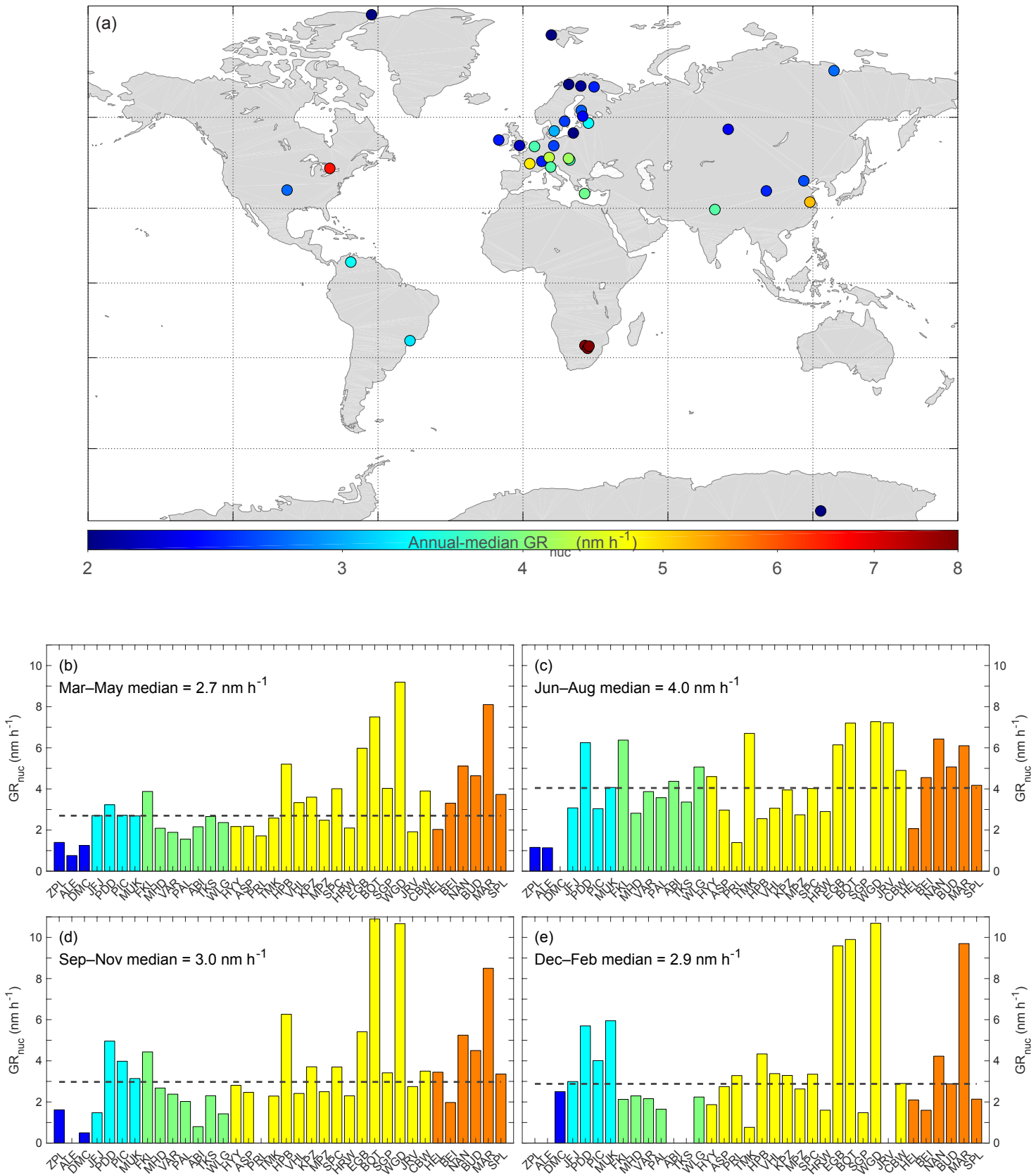

Figure 5. Annual-median (a) and seasonal-median (b-e) particle growth rates at the different measurement sites. The dashed lines in panels (b-e) show the median seasonal values, and the color scheme represents the classification of the sites into polar, high-altitude, remote, rural, and urban environments.

$\left(2.9 \mathrm{~nm} \mathrm{~h}^{-1}\right)$. Exceptions are the three South African stations (BOT, WGD, MAR), which showed considerably higher median GR through the year (from September to May), except for the period June-August, when the median GR values were comparable with other stations and closer to the overall median GR. Also, the Egbert site (EGB) in Canada showed high median GR values (about $10 \mathrm{~nm} \mathrm{~h}^{-1}$ ) during the pe- riod December-February, possibly due to increased anthropogenic impact during wintertime.

When looking at the seasonal variability in the three quantities discussed above, the observed behavior of the particle GR is the easiest one to explain. Earlier studies based on measurements in rural or remote locations have typically observed the highest values of GR during the summer and ascribed this feature to the higher emissions of biogenic aerosol 
precursor compounds at higher ambient temperatures during the summer compared with other seasons (Dal Maso et al., 2007; Nieminen et al., 2014; Pryor et al., 2010; Liao et al., 2014; Asmi et al., 2016). The situation is more complicated in environments affected strongly by anthropogenic activities, e.g., in practically all urban areas, where a large fraction of the compounds contributing to GR may originate from anthropogenic precursors (e.g., Vakkari et al., 2015). Emissions of anthropogenic aerosol precursor compounds may peak during any time of year, depending on human habits and requirements influenced by weather and climate (e.g., heat and energy production), yet their atmospheric oxidation to condensable vapors is expected to be strongest during summer in most of the environments. It is likely that the strong atmospheric photochemistry, coupled with high biogenic emissions of aerosol precursor vapors, largely explains the almost universal summer maximum in GR at the sites considered here. Recently, Dall'Osto et al. (2018) analyzed the chemical composition of 30-60 nm particles during NPF events at 24 sites across Europe and showed that the growth of the particles was dominated by secondary organic aerosol formation.

The NPF frequency had a clear summer-to-winter contrast similar to GR but, contrary to GR, it peaked in March-May rather than in June-August at many of the sites. A regional modeling study (Pietikäinen et al., 2014) indicated that the monthly average boundary layer burden of freshly nucleated $3 \mathrm{~nm}$ particles (a quantity that depends on both the NPF event frequency and particle formation rates) peaks in May-July in Europe. We find that the seasonal cycle of the particle formation rate $J_{\text {nuc }}$ was rather weak for most of the sites, yet it appeared to follow the seasonal cycle of the NPF frequency slightly better than that of GR. Several factors might contribute to these differences. The most apparent of them are that, compared with GR, the occurrence and strength of atmospheric NPF are expected to be more sensitive to the gas-phase sulfuric acid concentration and preexisting aerosol loading and less sensitive to low-volatility oxidation product concentrations of biogenic vapors (e.g., Westervelt et al., 2014; Dunne et al., 2016). Furthermore, the value of $J_{\text {nuc }}$ is affected not only by the strength of NPF but also by the GR of particles starting from the nanometer size as well as the preexisting aerosol load affecting the coagulation sink (e.g., Lehtinen et al., 2007). This is because during the growth of the initial nucleated particles these particles are continuously scavenged by coagulation with the preexisting aerosol.

\subsection{Relationships between the relevant quantities and implications}

The annual-median particle formation rate and GR were positively correlated with each other when considering all the 36 measurement sites together (Pearson correlation coefficient for the logarithmic values is $r=0.72, p<0.01$ ), as well as for the subsets of high-altitude and rural sites (Fig. 6). The other environments did not show such a relation since in

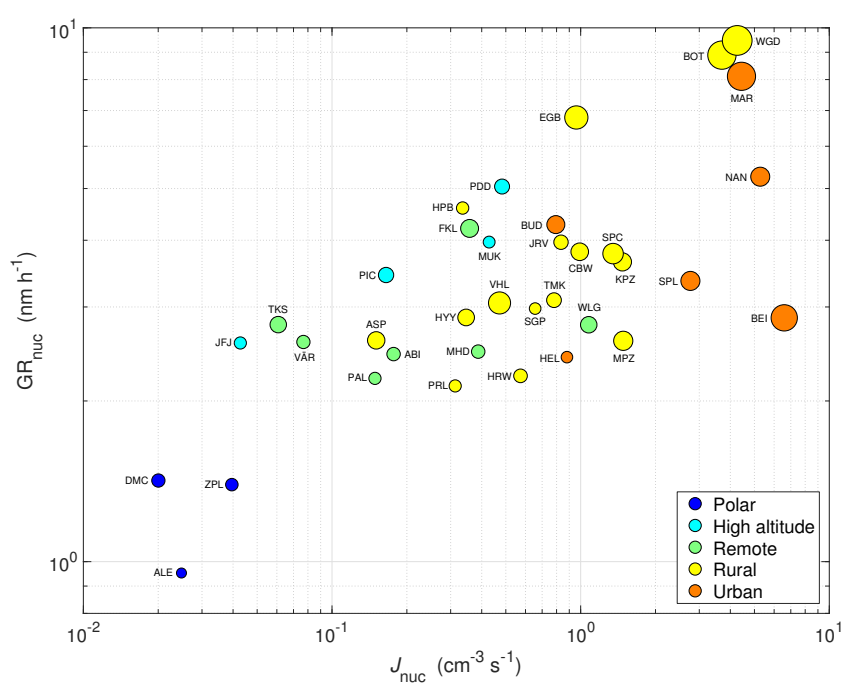

Figure 6. Annual-median, site-specific particle formation rate as a function of the corresponding growth rate. The marker size is proportional to the annual-median NPF frequency and the marker colors show the environment types of the sites.

these environments either the site-specific particle GRs (at rural sites) or formation rates (at polar, high-altitude, and urban sites) had weak variability and were concentrated in a relatively narrow range of annual-median values. The positive relation between $J_{\text {nuc }}$ and GR was identifiable among the rural sites in all the seasons (results not shown here) and even among the remote sites during the spring and autumn.

On an annual basis, the particle formation and GRs had a tendency to increase with increasing NPF event frequency among the different measurement sites (Fig. 6). A positive, yet moderate, correlation between $J_{\text {nuc }}$ and NPF event frequency was also observed when analyzing different seasons individually (results not shown here), as well as within the rural and remote subsets of the sites. The relation between GR and NPF event frequency was rather weak and remained so during the different seasons (results not shown here). None of the environments alone showed any sign of a relation between GR and NPF event frequency on an annual basis, but during summer a positive relationship was identifiable for the rural subset of the sites.

Intuitively, one would expect a certain degree of correlation among $J_{\text {nuc }}$, GR, and NPF event frequency because higher values of all these quantities are favored by higher gas-phase production rates of low-volatility vapors and by lower preexisting aerosol loadings (e.g., Kulmala and Kerminen, 2008; Westervelt et al., 2014). However, there are many other factors and processes that may cause a scatter in these relations. These factors and processes include the environmental and seasonal variability in

i. the dominant NPF mechanism (Kulmala et al., 2014; Dunne et al., 2016); 
ii. the availability of agents (ions, ammonia, amines, etc.) that are needed to stabilize molecular clusters containing sulfuric acid (Kirkby et al., 2011; Almeida et al., 2013; Schobesberger et al., 2015);

iii. the mixture of compounds responsible for the main growth of newly formed particles (see Vakkari et al., 2015, and references therein); and

iv. meteorological conditions, which can indirectly influence the various processes and factors mentioned in (i), (ii), and (iii).

In our data set there was a considerable amount of scatter in each of the relationships among $J_{\text {nuc }}$, GR, and NPF event frequency, which suggests that the values of these three quantities are affected by multiple factors with different degrees of importance among the individual locations.

In spite of the above discrepancies, the analysis of observed values of $J_{\text {nuc }}$, GR, and NPF event frequency allowed us to make certain general statements on the importance of regional NPF. We need to keep in mind that regional NPF events considered in this study typically last at least for a few hours and, as discussed earlier, that particles in the size range $10-25 \mathrm{~nm}$ in diameter are not very susceptible to coagulation and other loss processes. First, increases in the number concentration of particles larger than $10 \mathrm{~nm}$ due to a single NPF event are expected to be in the range from a few hundred to a few thousand particles per cubic centimeter per event at remote locations and in the range from a few thousand up to more than $10^{5}$ particles per cubic centimeter per event in rural and urban locations. If these numbers are combined with the observed NPF event frequencies, and compared with total particle number concentrations measured in different types of environments (see, e.g., Asmi et al., 2013), it becomes clear that regional NPF is capable of explaining a dominant fraction of the total particle number concentration in both remote and polluted continental locations. This dominance may persist throughout the year in some of the locations, while being restricted to one to three seasons in some other locations. In different urban environments, there has been shown to be considerable variation in the contribution of NPF to the total particle number (Reche et al., 2011; Beddows et al., 2015). Second, depending on the location and season, we may estimate that it typically takes from a few hours to a couple of days for the newly formed particles to reach sizes larger than 50-100 $\mathrm{nm}$ in diameter, at which size they may act as cloud condensation nuclei (CCN) (see, e.g., Kerminen et al., 2012). Our data suggest that in remote and rural locations, atmospheric $\mathrm{CCN}$ production associated with NPF tends to be most effective during summer and least effective during winter. Urban locations do not show any consistent seasonal pattern in this respect. Third, although regional NPF and the subsequent particle growth appear to be rather weak in polar areas during most of the year, the overall importance of atmospheric NPF for aerosol concentra- tions in polar areas is difficult to estimate based on our data. This is partly due to the limited number of continuous measurements available from polar sites and partly because of the challenges in capturing atmospheric NPF that either have very low particle formation and growth rates or have overall characteristics that considerably differ from those in lowerlatitude continental locations. Furthermore, polar and remote locations typically have lower concentrations of CCN-sized particles than anthropogenically influenced urban areas; thus the climatic importance of NPF cannot be evaluated based only on NPF frequency and particle formation and growth rates. In a recent modeling study, NPF influenced by ammonia emissions from a seabird colony was shown to significantly contribute to cooling in the Arctic area (Croft et al., 2016)

\section{Summary and conclusions}

By collecting a database on continuous particle number size distribution measurements at 36 continental sites worldwide, we investigated the overall and seasonal behavior of regional new particle formation in five different environmental regimes ranging from polar areas and remote sites to heavily polluted megacities.

We found regional NPF events to take place at all the measurement sites throughout the year, with the exception of December-February at the sites at high latitudes (ZPL, ALE, ABI, and TKS). NPF was most common (site median of seasonal-median NPF frequencies of about $30 \%$ ) during the Northern Hemisphere spring and least common (less than $10 \%$ ) during winter. No clear spatial pattern in the frequency of NPF according to environment type was observed, except that NPF events seemed to be most rare in polar areas during most seasons. We found that the formation rates of 10 $25 \mathrm{~nm}$ particles $\left(J_{\text {nuc }}\right)$ during the NPF events have a tendency to increase with an increasing degree of anthropogenic influence, being 1 to 2 orders of magnitude higher in urban areas compared with most of the remote and polar sites. The seasonal variability in $J_{\text {nuc }}$ was quite modest at most of the sites. We did not find any systematic environmental pattern for the growth rate (GR) of 10-25 $\mathrm{nm}$ particles during the NPF events, except that the GR was overall lowest in the polar regions. For the vast majority of the sites, the seasonal-median values of GR were the highest during the local summer and the lowest during the local winter. The observed values of $J_{\text {nuc }}$, GR, and NPF indicate that regional NPF can explain a dominant fraction of the total particle number concentration and give an important contribution to the $\mathrm{CCN}$ population, at both remote and heavily polluted continental locations.

We found that the connection among $J_{\text {nuc }}$, GR, and NPF event frequency was at best moderate among the different measurement sites, as well as among the sites belonging to a certain environmental regime. The apparent lack of a strong relation among these three quantities is understandable due 
to the environmental and seasonal variability in the dominant NPF mechanisms, in the abundances of compounds contributing to the initial steps of NPF and subsequent particle growth, and in the prevailing meteorological conditions. For future studies, it would be very valuable to make detailed investigations on the interdependencies among $J_{\text {nuc }}$, GR, and NPF event frequency, at both single measurement sites and among sites of seemingly similar environmental characteristics.

The data derived here will be helpful in evaluating, and possibly also in constraining, regional and large-scale atmospheric models that simulate aerosol formation and dynamics. However, it is also clear that more data similar to those presented in this study will be needed to better understand atmospheric NPF and its regional importance. Of specific importance in this respect are different urban areas practically all over the world, additional remote and rural locations in North America, Asia, and most of the Southern Hemisphere, and locations in polar areas. Furthermore, expanding the continental observations presented in this study to at least a few locations over the oceans covering $71 \%$ of the Earth's surface is needed for a comprehensive understanding of the global aerosol system and its effects on the global climate. For purely modeling purposes, or for the complementary use of models and in situ field and satellite measurements, it is probably sufficient to have particle number size distribution data down to a few nanometers (maximum $10 \mathrm{~nm}$ ) in particle diameter. For a better understanding of NPF in different environments and comparison to corresponding laboratory data, such data should preferably be extended down to $1.5-3 \mathrm{~nm}$ in particle diameter and ideally be complemented by measurements of the chemical composition of the growing clusters.

Data availability. The data sets analyzed in this study (NPF event frequencies and formation and growth rates) are available from the corresponding author upon request (tuomo.nieminen@uef.fi).

Author contributions. MK, TN, VMK, and TP designed the study, and TN performed the data analysis. TN, MK, VMK, and TP interpreted the results and wrote the manuscript. All the other co-authors provided measurement data and contributed to writing and commenting on the paper.

Competing interests. The authors declare that they have no conflict of interest.

Acknowledgements. This work was supported by the Academy of Finland Centres of Excellence program (project numbers 272041, 1118615, 307331), ACTRIS-2 under the European Union research infrastructure action in the frame of the H2020 program for "Integrating and opening existing national and regional research infrastructures of European interest" (grant agreement 654109), EU-
SAAR (R113-CT-2006-026140), and EUCAARI (0136 833-2). MeteoSwiss is acknowledged for their long-term financial support since 1995 within the Swiss component of the Global Atmosphere Watch program of the World Meteorological Organization to the operations at the Jungfraujoch site. The research at the Zeppelin, Pico Espejo, and Aspvreten stations has been carried out with the help of funding from the Swedish Research Council (Vetenskaprådet), Swedish Environmental Protection Agency (Naturvårdsverket), and Swedish International Development Cooperation Agency (SIDA). The measurements at the Vavihill station are part of the Swedish MERGE strategic research area. Continuous aerosol measurements at the Melpitz site were supported by the German Federal Ministry for the Environment (BMU) grants F\&E 370343200 ("Erfassung der Zahl feiner und ultrafeiner Partikel in der Außenluft") and F\&E 371143232 ("Trendanalysen gesundheitsgefährdender Fein- und Ultrafeinstaubfraktionen unter Nutzung der im German Ultrafine Aerosol Network (GUAN) ermittelten Immissionsdaten durch Fortführung und Interpretation der Messreihen”). For the Tiksi and Pallas sites, we acknowledge the funding from the Academy of Finland projects "Greenhouse gas, aerosol and albedo variations in the changing Arctic"(project number 269095) and "Novel Assessment of Black Carbon in the Eurasian Arctic: From Historical Concentrations and Sources to Future Climate Impacts" (NABCEA, project number 296302), and the funding from the European Union's Horizon 2020 programs under grant agreement no. 727890 (INTAROS). Environment and Climate Change Canada is acknowledged for operating the Alert and Egbert sites. For the Budapest site, the financial support by the National Research, Development and Innovation Office, Hungary (contracts K116788 and PD124283), is acknowledged. The measurements at the Botsalano, Welgegund, and Marikana sites received funding from Academy of Finland projects "Air pollution in Southern Africa" (project number 117505) and "Atmospheric monitoring capacity building in Southern Africa" (project number 132640), from North-West University, and from the Vilho, Yrjö and Kalle Väisälä Foundation. Measurements at Tomsk were carried out under support of the Department of Earth Sciences RAS. Measurements at Mukteshwar were performed with financial support by the Ministry of Foreign Affairs of Finland, Academy of Finland (264242, 268004, 284536), TEKES Finland, and DBT India (2634/31/2015). The Harwell measurement station was supported by the UK Department for Environment, Food and Rural Affairs. Institutional research funding IUT2011 and IUT20-52 of the Estonian Ministry of Education and Research is acknowledged for the Järvselja site.

We acknowledge the following researchers for providing data from several stations: Nicolas Bukowiecki, Ernest Weingartner, and Martine Collaud Coen (Jungfraujoch site); Thomas Tuch and Wolfram Birmili (Melpitz); Moa Sporre (Vavihill and Aspvreten), David Picard, Paolo Villani, Hervé Venzac, and Paolo Laj (Puy de Dome); Giorgos Kouvarakis and Nikos Kalivitis (Finokalia); Dan Veber (Alert); and Sander Mirme (Järvselja).

Edited by: Fangqun Yu

Reviewed by: two anonymous referees 


\section{References}

Almeida, J., Schobesberger, S., Kürten, A., Ortega, I. K., Kupiainen-Määttä, O., Praplan, A., Adamov, A., Amorim, A., Bianchi, F., Breitenlechner, M., David, A., Dommen, J., Donahue, N. M., Downard, A., Dunne, E., Duplissy, J., Ehrhart, S., Flagan, R. C., Franchin, A., Guida, R., Hakala, J., Hansel, A., Heinritzi, M., Henschel, H., Jokinen, T., Junninen, H., Kajos, M., Kangasluoma, J., Keskinen, H., Kupc, A., Kurtén, T., Kvashin, A. N., Laaksonen, A., Lehtipalo, K., Leiminger, M., Leppä, J., Loukonen, V., Makhmutov, V., Mathot, S., McGrath, M. J., Nieminen, T., Olenius, T., Onnela, A., Petäjä, T., Riccobono, F., Riipinen, I., Rissanen, M., Rondo, L., Ruuskanen, T., Santos, F. D., Sarnela, N., Schallhart, S., Schnitzhofer, R., Seinfeld, J. H., Simon, M., Sipilä, M., Stozhkov, Y., Stratmann, F., Tomé, A., Tröstl, J., Tsagkogeorgas, G., Vaattovaara, P., Viisanen, Y., Virtanen, A., Vrtala, A., Wagner, P. E., Weingartner, E., Wex, H., Williamson, C., Wimmer, D., Ye, P., Yli-Juuti, T., Carslaw, K. S., Kulmala, M., Curtius, J., Baltensperger, U., Worsnop, D. R., Vehkamäki, H., and Kirkby, J.: Molecular understanding of sulphuric acid-amine particle nucleation in the atmosphere, Nature, 502, 359-363, 2013.

Apte, J. S., Marshall, J. D., Cohen, A. J., and Brauer, M.: Addressing global mortality from ambient $\mathrm{PM}_{2.5}$, Environ. Sci. Technol., 49, 8057-8066, 2015.

Asmi, A., Collaud Coen, M., Ogren, J. A., Andrews, E., Sheridan, P., Jefferson, A., Weingartner, E., Baltensperger, U., Bukowiecki, N., Lihavainen, H., Kivekäs, N., Asmi, E., Aalto, P. P., Kulmala, M., Wiedensohler, A., Birmili, W., Hamed, A., O’Dowd, C., Jennings, S. G., Weller, R., Flentje, H., Fjaeraa, A. M., Fiebig, M., Myhre, C. L., Hallar, A. G., Swietlicki, E., Kristensson, A., and Laj, P.: Aerosol decadal trends - Part 2: In-situ aerosol particle number concentrations at GAW and ACTRIS stations, Atmos. Chem. Phys., 13, 895-916, https://doi.org/10.5194/acp-13-8952013, 2013.

Asmi, E., Kivekäs, N., Kerminen, V.-M., Komppula, M., Hyvärinen, A.-P., Hatakka, J., Viisanen, Y., and Lihavainen, H.: Secondary new particle formation in Northern Finland Pallas site between the years 2000 and 2010, Atmos. Chem. Phys., 11, 12959-12972, https://doi.org/10.5194/acp-11-12959-2011, 2011.

Asmi, E., Kondratyev, V., Brus, D., Laurila, T., Lihavainen, H., Backman, J., Vakkari, V., Aurela, M., Hatakka, J., Viisanen, Y., Uttal, T., Ivakhov, V., and Makshtas, A.: Aerosol size distribution seasonal characteristics measured in Tiksi, Russian Arctic, Atmos. Chem. Phys., 16, 1271-1287, https://doi.org/10.5194/acp16-1271-2016, 2016.

Backman, J., Rizzo, L. V., Hakala, J., Nieminen, T., Manninen, H. E., Morais, F., Aalto, P. P., Siivola, E., Carbone, S., Hillamo, R., Artaxo, P., Virkkula, A., Petäjä, T., and Kulmala, M.: On the diurnal cycle of urban aerosols, black carbon and the occurrence of new particle formation events in springtime São Paulo, Brazil, Atmos. Chem. Phys., 12, 11733-11751, https://doi.org/10.5194/acp-12-11733-2012, 2012.

Beddows, D. C. S., Harrison, R. M., Green, D. C., and Fuller, G. W.: Receptor modelling of both particle composition and size distribution from a background site in London, UK, Atmos. Chem. Phys., 15, 10107-10125, https://doi.org/10.5194/acp-15-101072015, 2015.

Berland, K., Rose, C., Pey, J., Culot, A., Freney, E., Kalivitis, N., Kouvarakis, G., Cerro, J. C., Mallet, M., Sartelet, K., Beckmann,
M., Bourriane, T., Roberts, G., Marchand, N., Mihalopoulos, N., and Sellegri, K.: Spatial extent of new particle formation events over the Mediterranean Basin from multiple ground-based and airborne measurements, Atmos. Chem. Phys., 17, 9567-9583, https://doi.org/10.5194/acp-17-9567-2017, 2017.

Bianchi, F., Tröstl, J., Junninen, H., Frege, C., Henne, S., Hoyle, C. R., Molteni, U., Herrmann, E., Adamov, A., Bukowiecki, N., Chen, X., Duplissy, J., Gysel, M., Hutterli, M., Kangasluoma, J., Kontkanen, J., Kürten, A., Manninen, H. E., Münch, S., Peräkylä, O., Petäjä, T., Rondo, L., Williamson, C., Weingartner, E., Curtius, J., Worsnop, D. R., Kulmala, M., Dommen, J., and Baltensperger, U.: New particle formation in the free troposphere: A question of chemistry and timing, Science, 352, 1109-1112, https://doi.org/10.1126/science.aad5456, 2016.

Birmili, W., Berresheim, H., Plass-Dülmer, C., Elste, T., Gilge, S., Wiedensohler, A., and Uhrner, U.: The Hohenpeissenberg aerosol formation experiment (HAFEX): a long-term study including size-resolved aerosol, $\mathrm{H}_{2} \mathrm{SO}_{4}, \mathrm{OH}$, and monoterpenes measurements, Atmos. Chem. Phys., 3, 361-376, https://doi.org/10.5194/acp-3-361-2003, 2003.

Boulon, J., Sellegri, K., Venzac, H., Picard, D., Weingartner, E., Wehrle, G., Collaud Coen, M., Bütikofer, R., Flückiger, E., Baltensperger, U., and Laj, P.: New particle formation and ultrafine charged aerosol climatology at a high altitude site in the Alps (Jungfraujoch, $3580 \mathrm{~m}$ a.s.l., Switzerland), Atmos. Chem. Phys., 10, 9333-9349, https://doi.org/10.5194/acp-109333-2010, 2010.

Boulon, J., Sellegri, K., Hervo, M., Picard, D., Pichon, J.-M., Fréville, P., and Laj, P.: Investigation of nucleation events vertical extent: a long term study at two different altitude sites, Atmos. Chem. Phys., 11, 5625-5639, https://doi.org/10.5194/acp11-5625-2011, 2011.

Brauer, M., Freedman, G., Frostad, J., van Donkelaar, A., Martin, R. V., Dentener, F., Dingenen, R. van, Estep, K., Amini, H., Apte, J. S., Balakrishnan, K., Barregard, L., Broday, D., Feigin, V., Ghosh, S., Hopke, P. K., Knibbs, L. D., Kokubo, Y., Liu, Y., Ma, S., Morawska, L., Sangrador, J. L. T., Shaddick, G., Anderson, H. R., Vos, T., Forouzanfar, M. H., Burnett, R. T., and Cohen, A.: Ambient Air Pollution Exposure Estimation for the Global Burden of Disease 2013, Environ. Sci. Technol., 50, 7988, https://doi.org/10.1021/acs.est.5b03709, 2016.

Bukowiecki, N., Weingartner, E., Gysel, M., Coen, M. C., Zieger, P., Herrmann, E., Steinbacher, M., Gäggeler, H. W., and Baltensperger, U.: A review of more than 20 years of aerosol observation at the high altitude research station Jungfraujoch, Switzerland (3580 m asl), Aerosol Air Qual. Res., 16, 764-788, 2016.

Carpenter, L. J., Archer, S. D., and Beale, R.: Ocean-atmosphere trace gas exchange. Chem. Soc. Rev. 41,6473-6506, 2012.

Charron, A., Birmili, W., and Harrison, R. M.: Factors influencing new particle formation at the rural site, Harwell, United Kingdom, J. Geophys. Res., 112, D14210, https://doi.org/10.1029/2007JD008425, 2007.

Croft, B., Wentworth, G. R., Martin, R. V., Leaitch, W. R., Murphy, J. G., Murphy, B. N., Kodros, J. K., Abbatt, J. P., and Pierce, J. R.: Contribution of Arctic seabird-colony ammonia to atmospheric particles and cloud-albedo radiative effect, Nat. Commun., 7, 13444, https://doi.org/10.1038/ncomms13444, 2016.

Crumeyrolle, S., Manninen, H. E., Sellegri, K., Roberts, G., Gomes, L., Kulmala, M., Weigel, R., Laj, P., and Schwarzen- 
boeck, A.: New particle formation events measured on board the ATR-42 aircraft during the EUCAARI campaign, Atmos. Chem. Phys., 10, 6721-6735, https://doi.org/10.5194/acp-106721-2010, 2010.

Dall'Osto, M., Beddows, D. C. S., Asmi, A., Poulain, L., Hao, L., Freney, E., Allan, J. D., Canagaratna, M., Crippa, M., Bianchi, F., Leeuw, G. de, Eriksson, A., Swietlicki, E., Hansson, H. C., Henzing, J. S., Granier, C., Zemankova, K., Laj, P., Onasch, T., Prevot, A., Putaud, J. P., Sellegri, K., Vidal, M., Virtanen, A., Simo, R., Worsnop, D., O’Dowd, C., Kulmala, M., and Harrison, R. M.: Novel insights on new particle formation derived from a pan-european observing system, Sci. Rep., 8, 1482, https://doi.org/10.1038/s41598-017-17343-9, 2018.

Dal Maso, M., Kulmala, M., Riipinen, I., Wagner, R., Hussein, T., Aalto, P. P., and Lehtinen, K. E. J.: Formation and growth of fresh atmospheric aerosols: eight years of aerosol size distribution data from SMEAR II, Hyytiälä, Finland, Boreal Environ. Res., 10, 323-336, 2005.

Dal Maso, M., Sogacheva, L., Aalto, P. P., Riipinen, I., Komppula, M., Tunved, P., Korhonen, L., Suur-uski, V., Hirsikko, A., Kurten, T., Kerminen, V.-M., Lihavainen, H., Viisanen, Y., Hansson, H.C., and Kulmala, M.: Aerosol size distribution measurements at four Nordic field stations: identification, analysis and trajectory analysis of new particle formation bursts Tellus B, 59, 350-361, 2007.

Ding, A., Nie, W., Huang, X., Chi, X., Sun, J., Kerminen, V.-M., Xu, Z., Guo, W., Petäjä, T., Yang, X., Kulmala, M., and Fu, C.: Longterm observation of air pollution-weather/climate interactions at the SORPES station: a review and outlook. Front. Environ. Sci. Eng., 10, 15, https://doi.org/10.1007/s11783-016-0877-3, 2016.

Dunne, E. M., Gordon, H., Kürten, A., Almeida, J., Duplissy, J., Williamson, C., Ortega, I. K., Pringle, K. J., Adamov, A., Baltensperger, U., Barmet, P., Benduhn, F., Bianchi, F., Breitenlechner, M., Clarke, A., Curtius, J., Dommen, J., Donahue, N. M., Ehrhart, S., Flagan, R. C., Franchin, A., Guida, R., Hakala, J., Hansel, A., Heinritzi, M., Jokinen, T., Kangasluoma, J., Kirkby, J., Kulmala, M., Kupc, A., Lawler, M. J., Lehtipalo, K., Makhmutov, V., Mann, G., Mathot, S., Merikanto, J., Miettinen, P., Nenes, A., Onnela, A., Rap, A., Reddington, C. L. S., Riccobono, F., Richards, N. A. D., Rissanen, M. P., Rondo, L., Sarnela, N., Schobesberger, S., Sengupta, K., Simon, M., Sipilä, M., Smith, J. N., Stozkhov, Y., Tomé, A., Tröstl, J., Wagner, P. E., Wimmer, D., Winkler, P. M., Worsnop, D. R., and Carslaw, K. S.: Global atmospheric particle formation from CERN CLOUD measurements, Science, 354, 1119-1124, https://doi.org/10.1126/science.aaf2649, 2016.

Hamed, A., Joutsensaari, J., Mikkonen, S., Sogacheva, L., Dal Maso, M., Kulmala, M., Cavalli, F., Fuzzi, S., Facchini, M. C., Decesari, S., Mircea, M., Lehtinen, K. E. J., and Laaksonen, A.: Nucleation and growth of new particles in Po Valley, Italy, Atmos. Chem. Phys., 7, 355-376, https://doi.org/10.5194/acp-7355-2007, 2007.

Hamed, A., Birmili, W., Joutsensaari, J., Mikkonen, S., Asmi, A., Wehner, B., Spindler, G., Jaatinen, A., Wiedensohler, A., Korhonen, H., Lehtinen, K. E. J., and Laaksonen, A.: Changes in the production rate of secondary aerosol particles in Central Europe in view of decreasing $\mathrm{SO}_{2}$ emissions between 1996 and 2006, Atmos. Chem. Phys., 10, 1071-1091, https://doi.org/10.5194/acp-10-1071-2010, 2010.
Hari, P. and Kulmala, M.: Station for Measuring EcosystemAtmosphere Relations (SMEAR II), Boreal Environ. Res., 10, 315-322, 2005.

Hatakka J., Aalto T., Aaltonen V., Aurela M., Hakola H., Komppula M., Laurila T., Lihavainen H., Paatero J., Salminen K., and Viisanen Y.: Overview of the atmospheric research activities and results at Pallas GAW station, Boreal Environ. Res., 8, 365-383, 2003.

Hussein, T., Martikainen, J., Junninen, H., Sogacheva, L., Wagner, R., Dal Maso, M., Riipinen, I., Aalto, P. P., and Kulmala, M.: Observation of regional new particle formation in the urban atmosphere, Tellus, 60B, 509-521, 2008.

Hyvärinen, A. P., Lihavainen, H., Komppula, M., Sharma, V. P., Kerminen, V.-M., Panwar, T. S., and Viisanen, Y.: Continuous measurements of optical properties of atmospheric aerosols in Mukteshwar, northern India, J. Geophys. Res., 114, D08207, https://doi.org/10.1029/2008JD011489, 2009.

IPCC (2013), Climate Change 2013: The Physical Science Basis. Contribution of Working Group I to the Fifth Assessment Report of the Intergovernmental Panel on Climate Change, edited by: Stocker, T. F., Qin, D., Plattner, G. K., Tignor, M., Allen, S. K., Boschung, J., Nauels, A., Xia, Y., Bex, V., and Midgley, P. M., Cambridge University Press, Cambridge, UK and New York, NY, USA, 2013.

Jaars, K., van Zyl, P. G., Beukes, J. P., Hellén, H., Vakkari, V., Josipovic, M., Venter, A. D., Räsänen, M., Knoetze, L., Cilliers, D. P., Siebert, S. J., Kulmala, M., Rinne, J., Guenther, A., Laakso, L., and Hakola, H.: Measurements of biogenic volatile organic compounds at a grazed savannah grassland agricultural landscape in South Africa, Atmos. Chem. Phys., 16, 15665-15688, https://doi.org/10.5194/acp-16-15665-2016, 2016.

Järvinen, E., Virkkula, A., Nieminen, T., Aalto, P. P., Asmi, E., Lanconelli, C., Busetto, M., Lupi, A., Schioppo, R., Vitale, V., Mazzola, M., Petäjä, T., Kerminen, V.-M., and Kulmala, M.: Seasonal cycle and modal structure of particle number size distribution at Dome C, Antarctica, Atmos. Chem. Phys., 13, 7473-7487, https://doi.org/10.5194/acp-13-7473-2013, 2013.

Kerminen, V.-M., Paramonov, M., Anttila, T., Riipinen, I., Fountoukis, C., Korhonen, H., Asmi, E., Laakso, L., Lihavainen, H., Swietlicki, E., Svenningsson, B., Asmi, A., Pandis, S. N., Kulmala, M., and Petäjä, T.: Cloud condensation nuclei production associated with atmospheric nucleation: a synthesis based on existing literature and new results, Atmos. Chem. Phys., 12, 1203712059, https://doi.org/10.5194/acp-12-12037-2012, 2012.

Kirkby, J., Curtius, J., Almeida, J., Dunne, E., Duplissy, J., Ehrhart, S., Franchin, A., Gagné, S., Ickes, L., Kürten, A., Kupc, A., Metzger, A., Riccobono, F., Rondo, L., Schobesberger, S., Tsagkogeorgas, G., Wimmer, D., Amorim, A., Bianchi, F., Breitenlechner, M., David, A., Dommen, J., Downard, A., Ehn, M., Flagan, R. C., Haider, S., Hansel, A., Hauser, D., Jud, W., Junninen, H., Kreissl, F., Kvashin, A., Laaksonen, A., Lehtipalo, K., Lima, J., Lovejoy, E. R., Makhutov, V., Mathot, S., Mikkilä, J., Minginette, P., Mogo, S., Nieminen, T., Onnela, A., Pereira, A., Petäjä, T., Schnitzhofer, R., Seinfeld, J. H., Sipilä, M., Stozhkov, Y., Stratmann, F., Tome, A., Vanhanen, J., Viisanen Y., Vrtala, A., Wagner, P. E., Walther, H., Weingartner, E., Wex, H., Winkler, P. M., Carslaw, K. S., Worsnop, D. R., Baltensperger, U., and Kulmala, M.: The role of sulfuric acid, ammonia and galactic cosmic rays in atmospheric aerosol nucleation, Nature, 476, 429-433, 2011. 
Kivekäs, N., Sun, J., Zhan, M., Kerminen, V.-M., Hyvärinen, A., Komppula, M., Viisanen, Y., Hong, N., Zhang, Y., Kulmala, M., Zhang, X.-C., Deli-Geer, and Lihavainen, H.: Long term particle size distribution measurements at Mount Waliguan, a highaltitude site in inland China, Atmos. Chem. Phys., 9, 5461-5474, https://doi.org/10.5194/acp-9-5461-2009, 2009.

Kristensson, A., Dal Maso, M., Swietlicki, E., Hussein, T., Zhou, J., Kerminen, V.-M., and Kulmala, M.: Characterization of new particle formation events at a background site in Southern Sweden: relation to air mass history, Tellus B, 60, 330-344, 2008.

Kulmala, M. and Kerminen, V.-M.: On the formation and growth of atmospheric nanoparticles, Atmos. Res., 90, 132-150, 2008.

Kulmala, M., Vehkamäki, H., Petäjä, T., Dal Maso, M., Lauri, A., Kerminen, V.-M., Birmili, W., and McMurry, P. H.: Formation and growth rates of ultrafine atmospheric particles: a review of observations, J. Aerosol Sci., 35, 143-176, 2004.

Kulmala, M., Petäjä, T., Nieminen, T., Sipilä, M., Manninen, H. E., Lehtipalo, K., Dal Maso, M., Aalto, P. P., Junninen, H., Paasonen, P., Riipinen, I., Lehtinen, K. E. J., Laaksonen, A., and Kerminen, V.-M.: Measurement of the nucleation of atmospheric aerosol particles, Nature Protoc., 7, 1651-1667, https://doi.org/10.1038/nprot.2012091, 2012.

Kulmala, M., Petäjä, T., Ehn, M., Thornton, J., Sipilä, M., Worsnop, D. R., and Kerminen, V.-M.: Chemistry of atmospheric nucleation: On the recent advances on precursor characterization and atmospheric cluster composition in connection with atmospheric new particle formation, Annu. Rev. Phys. Chem., 65, 21-37, 2014.

Kulmala, M., Petäjä, T., Kerminen, V.-M., Kujansuu, J., Ruuskanen, T., Ding, A., Nie, W., Hu, M., Wang, Z., Wu, Z., Wang, L., and Worsnop, D. R.: On secondary new particle formation in China, Front. Environ. Sci. Eng., 10, 08, https://doi.org/10.1007/s11783-016-0850-1, 2016.

Kyrö, E.-M., Väänänen, R., Kerminen, V.-M., Virkkula, A., Petäjä, T., Asmi, A., Dal Maso, M., Nieminen, T., Juhola, S., Shcherbinin, A., Riipinen, I., Lehtipalo, K., Keronen, P., Aalto, P. P., Hari, P., and Kulmala, M.: Trends in new particle formation in eastern Lapland, Finland: effect of decreasing sulfur emissions from Kola Peninsula. Atmos. Chem. Phys., 14, 4383-4396, https://doi.org/10.5194/acp-14-4383-2014, 2014.

Laakso, L., Laakso, H., Aalto, P. P., Keronen, P., Petäjä, T., Nieminen, T., Pohja, T., Siivola, E., Kulmala, M., Kgabi, N., Molefe, M., Mabaso, D., Phalatse, D., Pienaar, K., and Kerminen, V.-M.: Basic characteristics of atmospheric particles, trace gases and meteorology in a relatively clean Southern African Savannah environment, Atmos. Chem. Phys., 8, 4823-4839, https://doi.org/10.5194/acp-8-4823-2008, 2008.

Lacressonniere, G., Peuch, V.-H., Vautard, R., Arteta, J., Deque, M., Joly, M., Josse, B., Marecal, V., and Saint-Martin, D.: European air quality in 2030s and 2050s: Impacts of global and regional emission trends and of climate change, Atmos. Environ., 92, 348-358, 2014.

Leaitch, W. R., Sharma, S., Huang, L., Toom-Sauntry, D., Chivulescu, A., Macdonald, A. M., von Salzen, K., Pierce, J. R., Bertram, A. K., Schroder, J. C., Shantz, N. C., Chang, R. Y.-W. and Norman, A.-L.: Dimethyl sulfide control of the clean summertime Arctic aerosol and cloud. Elem. Sci. Anthr. 1, 17, https://doi.org/10.12952/journal.elementa.000017, 2013.
Lehtinen, K. E. J., Dal Maso, M., Kulmala, M., and Kerminen V.M.: Estimating nucleation rates from apparent particle formation rates and vice-versa: Revised formulation of the KerminenKulmala equation, J. Aerosol Sci., 38, 988-994, 2007.

Lelieveld, J., Evans, J. S., Fnais, M., Giannaki, D., and Pozzer, A.: The contribution of outdoor air pollution sources to premature mortality on a global scale, Nature, 525, 367-371, 2015.

Liao, L., Kerminen, V.-M., Boy, M., Kulmala, M., and Dal Maso, M.: Temperature influence on the natural aerosol budget over boreal forests, Atmos. Chem. Phys., 14, 8295-8308, https://doi.org/10.5194/acp-14-8295-2014, 2014.

Lohila, A., Penttilä, T., Jortikka, S., Aalto, T., Anttila P., Asmi, E., Aurela, M., Hatakka, J., Hellén, H., Henttonen, H., Hänninen, P., Kilkki, J., Kyllönen, K., Laurila, T., Lepistö, A., Lihavainen, H., Makkonen, U., Paatero, J., Rask, M., Sutinen, R., Tuovinen, J.-P., Vuorenmaa, J., and Viisanen Y.: Preface to the special issue on integrated research of atmosphere, ecosystems and environment at Pallas, Boreal Environ. Res., 20, 431-454, 2015.

Makkonen, R., Asmi, A., Kerminen, V.-M., Boy, M., Arneth, A., Hari, P., and Kulmala, M.: Air pollution control and decreasing new particle formation lead to strong climate warming, Atmos. Chem. Phys., 12, 1515-1524, https://doi.org/10.5194/acp12-1515-2012, 2012.

Manninen, H. E., Nieminen, T., Asmi, E., Gagné, S., Häkkinen, S., Lehtipalo, K., Aalto, P., Vana, M., Mirme, A., Mirme, S., Hõrrak, U., Plass-Dülmer, C., Stange, G., Kiss, G., Hoffer, A. Törő, N., Moerman, M., Henzing, B., de Leeuw, G., Brinkenberg, M., Kouvarakis, G. N., Bougiatioti, A., Mihalopoulos, N., O’Dowd, C., Ceburnis, D., Arneth, A., Svenningsson, B., Swietlicki, E., Tarozzi, L., Decesari, S., Facchini, M. C., Birmili, W., Sonntag, A., Wiedensohler, A., Boulon, J., Sellegri, K., Laj, P., Gysel, M., Bukowiecki, N., Weingartner, E., Wehrle, G., Laaksonen, A., Hamed, A., Joutsensaari, J., Petäjä, T., Kerminen, V.-M., and Kulmala, M.: EUCAARI ion spectrometer measurements at 12 European sites - analysis of new particle formation events, Atmos. Chem. Phys., 10, 7907-7927, https://doi.org/10.5194/acp10-7907-2010, 2010.

Matvienko, G. G., Belan, B. D., Panchenko, M. V., Romanovskii, O. A., Sakerin, S. M., Kabanov, D. M., Turchinovich, S. A., Turchinovich, Y. S., Eremina, T. A., Kozlov, V. S., Terpugova, S. A., Pol'kin, V. V., Yausheva, E. P., Chernov, D. G., Zhuravleva, T. B., Bedareva, T. V., Odintsov, S. L., Burlakov, V. D., Nevzorov, A. V., Arshinov, M. Y., Ivlev, G. A., Savkin, D. E., Fofonov, A. V., Gladkikh, V. A., Kamardin, A. P., Balin, Y. S., Kokhanenko, G. P., Penner, I. E., Samoilova, S. V., Antokhin, P. N., Arshinova, V. G., Davydov, D. K., Kozlov, A. V., Pestunov, D. A., Rasskazchikova, T. M., Simonenkov, D. V., Sklyadneva, T. K., Tolmachev, G. N., Belan, S. B., Shmargunov, V. P., Kozlov, A. S., and Malyshkin, S. B.: Complex experiment on studying the microphysical, chemical, and optical properties of aerosol particles and estimating the contribution of atmospheric aerosolto-earth radiation budget, Atmos. Meas. Tech., 8, 4507-4520, https://doi.org/10.5194/amt-8-4507-2015, 2015.

Merikanto, J., Spracklen, D. V., Mann, G. W., Pickering, S. J., and Carslaw, K. S.: Impact of nucleation on global CCN, Atmos. Chem. Phys., 9, 8601-8616, https://doi.org/10.5194/acp-9-86012009, 2009. 
Mihalopoulos, N., Stephanou, E., Kanakidou, M., Pilitsidis, S., and Bousquet, P.: Tropospheric aerosol ionic composition above the Eastern Mediterranean region, Tellus B, 49, 314-326, 1997.

Neitola, K., Asmi, E., Komppula, M., Hyvärinen, A.-P., Raatikainen, T., Panwar, T. S., Sharma, V. P., and Lihavainen, H.: New particle formation infrequently observed in $\mathrm{Hi}-$ malayan foothills - why?, Atmos. Chem. Phys., 11, 8447-8458, https://doi.org/10.5194/acp-11-8447-2011, 2011.

Németh, Z. and Salma, I.: Spatial extension of nucleating air masses in the Carpathian Basin. Atmos. Chem. Phys., 14, 8841-8848, https://doi.org/10.5194/acp-14-8841-2014, 2014.

Nieminen, T., Asmi, A., Dal Maso, M., P. Aalto, P., Keronen, P., Petäjä, T., Kulmala, M., and Kerminen, V.-M.: Trends in atmospheric new-particle formation: 16 years of observations in a boreal-forest environment, Boreal Environ. Res., 19 (suppl. B), 191-214, 2014.

Noe, S. M., Niinemets, Ü., Krasnova, A., Krasnov, D., Motallebi, A., Kängsepp, V., Jõgiste, K., Hõrrak, U., Komsaare, K., Mirme, S., Vana, M., Tammet, H., Bäck, J., Vesala, T., Kulmala, M., Petäjä, T., and Kangur, A.: SMEAR Estonia: Perspectives of a large-scale forest ecosystem - atmosphere research infrastructure, Forestry Studies - Metsanduslikud Uurimused, 63, 56-84, https://doi.org/10.1515/fsmu-2015-0009, 2015.

O'Connor, T. C., Jennings, S. G., and O'Dowd, C. D.: Highlights from 50 years of Aerosol Measurements at Mace Head, Atmos. Res., 90, 338-355, https://doi.org/10.1016/j.atmosres.2008.08.014, 2008.

O’Dowd, C., Ceburnis, D., Ovadnevaite, J., Vaishya, A., Rinaldi, M., and Facchini, M. C.: Do anthropogenic, continental or coastal aerosol sources impact on a marine aerosol signature at Mace Head?, Atmos. Chem. Phys., 14, 10687-10704, https://doi.org/10.5194/acp-14-10687-2014, 2014.

Parworth, C., Fast, J., Mei, F., Shippert, T., Sivaraman, C., Tilp, A., Watson, T., and Zhang, Q.: Long-term measurements of submicrometer aerosol chemistry at the Southern Great Plains (SGP) using an Aerosol Chemical Speciation Monitor (ACSM), Atmos. Environ., 106, 43-55, 2015.

Pauraite, J., Mordas, G., Bycenkiene, S., and Ulevicius, V.: Spatial and temporal analysis of organic and black carbon mass concentrations in Lithuania, Atmosphere, 6, 1229-1242, https://doi.org/10.3390/atmos6081229, 2015.

Peng, J. F.-, Hu, M., Wang, Z. B., Huang, X. F., Kumar, P., Wu, Z. J., Guo, S., Yue, D. L., Shang, D. J., Zheng, Z., and He, L. Y.: Submicron aerosols at thirteen diversified sites in China: size distribution, new particle formation and corresponding contribution to cloud condensation nuclei production, Atmos. Chem. Phys., 14, 10249-10265, https://doi.org/10.5194/acp-14-102492014, 2014.

Pierce, J. R., Westervelt, D. M., Atwood, S. A., Barnes, E. A., and Leaitch, W. R.: New-particle formation, growth and climaterelevant particle production in Egbert, Canada: analysis from 1 year of size-distribution observations, Atmos. Chem. Phys., 14, 8647-8663, https://doi.org/10.5194/acp-14-8647-2014, 2014.

Pietikäinen, J.-P., Mikkonen, S., Hamed, A., Hienola, A. I., Birmili, W., Kulmala, M., and Laaksonen, A.: Analysis of nucleation events in the European boundary layer using the regional aerosol-climate model REMO-HAM with a solar radiationdriven OH-proxy, Atmos. Chem. Phys., 14, 11711-11729, https://doi.org/10.5194/acp-14-11711-2014, 2014.
Pietikäinen, J.-P., Kupiainen, K., Klimont, Z., Makkonen, R., Korhonen, H., Karinkanta, R., Hyvärinen, A.-P., Karvosenoja, N., Laaksonen, A., Lihavainen, H., and Kerminen, V.-M.: Impacts of emission reductions on aerosol radiative effects, Atmos. Chem. Phys., 15, 5501-5519, https://doi.org/10.5194/acp15-5501-2015, 2015.

Pryor, S. C., Spaulding, A. M., and Barthelmie, R. J.: New particle formation in the Midwestern USA: Event characteristics, meteorological context and vertical profiles, Atmos. Environ., 44, 4413-4425, 2010.

Qi, X. M., Ding, A. J., Nie, W., Petäjä, T., Kerminen, V.-M., Herrmann, E., Xie, Y. N., Zheng, L. F., Manninen, H., Aalto, P., Sun, J. N., Xu, Z. N., Chi, X. G., Huang, X., Boy, M., Virkkula, A., Yang, X.-Q., Fu, C. B., and Kulmala, M.: Aerosol size distribution and new particle formation in the western Yangtze River Delta of China: 2 years of measurements at the SORPES station. Atmos. Chem. Phys., 15, 12445-12464, https://doi.org/10.5194/acp-15-12445-2015, 2015.

Reche, C., Querol, X., Alastuey, A., Viana, M., Pey, J., Moreno, T., Rodriguez, S., Gonzalez, Y., Fernandez-Camacho, R., Sanchez de la Campa, A. M., de la Rosa, J., Dall'Osto, M., Prévôt, A. S. H., Hueglin, C., Harrison, R. M., and Quincey, P.: New considerations for $\mathrm{PM}$, black carbon and particle number concentration for air quality monitoring across different European cities, Atmos. Chem. Phys., 11, 6207-6227, https://doi.org/10.5194/acp11-6207-2011, 2011.

Rose, C., Sellegri, K., Freney, E., Dupuy, R., Colomb, A., Pichon, J. M., Ribeiro, M., Bourianne, T., Burnet, F., and Schwarzenboeck, A.: Airborne measurements of new particle formation in the free troposphere above the Mediterranean Sea during the HYMEX campaign, Atmos. Chem. Phys., 15, 10203-10218, https://doi.org/10.5194/acp-15-10203-2015, 2015.

Rupakheti, M., Leaitch, W. R., Lohmann, U., Hayden, K., Brickell, P., Lu, G., Li, S.-M., Toom-Sauntry, D., Bottenheim, J. W., Brook, J. R., Vet, R., Jayne, J. T., and Worsnop, D. R.: An intensive study of the size and composition of submicron atmospheric aerosols at a rural site in Ontario, Canada, Aerosol Sci. Technol., 39, 722-736, 2005.

Russchenberg, H., Bosveld, F., Swart, D., ten Brink, H., de Leeuw, G., Uijlenhoet, R., Arbesser-Rastburg, B., van der Marel, H., Ligthart, L., Boers, R., and Apituley, A.: Ground-Based Atmospheric Remote Sensing in the Netherlands: European Outlook, The Institute of Electronics, Inform. Comm. Eng., E88-B, 22522258, 2005.

Salma, I., Németh, Z., Kerminen, V.-M., Aalto, P., Nieminen, T., Weidinger, T., Molnár, Á., Imre, K., and Kulmala, M.: Regional effect on urban atmospheric nucleation, Atmos. Chem. Phys., 16, 8715-8728, https://doi.org/10.5194/acp-16-8715-2016, $2016 \mathrm{a}$.

Salma, I., Németh, Z., Weidinger, T., Kovács, B., and Kristóf, G.: Measurement, growth types and shrinkage of newly formed aerosol particles at an urban research platform, Atmos. Chem. Phys., 16, 7837-7851, https://doi.org/10.5194/acp16-7837-2016, $2016 \mathrm{~b}$.

Schmeissner, T., Krejci, R., Ström, J., Birmili, W., Wiedensohler, A., Hochschild, G., Gross, J., Hoffmann, P., and Calderon, S.: Analysis of number size distributions of tropical free tropospheric aerosol particles observed at Pico Espejo (4765 m a.s.l.), Venezuela, Atmos. Chem. Phys., 11, 3319-3332, https://doi.org/10.5194/acp-11-3319-2011, 2011. 
Schobesberger, S., Franchin, A., Bianhi, F., Rondo, L., Duplissy, J., Kurten, A., Ortega, I. K., Metzger, A., Schnitzhofer, R., Almeida, J., Amorim, A., Dommen, J., Dunne, E. M., Ehn, M., Gagne, S., Ickes, L., Junninen, H., Hansel, A., Kerminen, V.-M., Kirkby, J., Kupc, A., Laaksonen, A., Lehtipalo, K., Mathot, S., Onnela, A., Petäjä, T., Riccobono, F., Santos, F. D., Sipilä, M., Tome, A., Tsagkogeorgas, G., Viisanen, Y., Wagner, P. E., Wimmer, D., Curtius, J., Donahue, N. M., Baltensperger, U., Kulmala, M., and Worsnop, D. R.: On the composition ammonia-sulfuric acid ion clusters during aerosol particle formation, Atmos. Chem. Phys., 15, 55-78, https://doi.org/10.5194/acp-15-55-2015, 2015.

Shen, L., Mickley, L. J., and Murray, L. T.: Influence of 2000-2050 climate change on particulate matter in the United States: results from a new statistical model, Atmos. Chem. Phys., 17, 43554367, https://doi.org/10.5194/acp-17-4355-2017, 2017.

Shindell, D., Faluvegi, G., Rotstayn, L., and Milly, G.: Spatial patterns of radiative forcing and surface temperature change, J. Geophys. Res., 120, 5385-5403, https://doi.org/10.1002/2014JD022752, 2015.

Slowik, J. G., Stroud, C., Bottenheim, J. W., Brickell, P. C., Chang, R. Y.-W., Liggio, J., Makar, P. A., Martin, R., Moran, M. D., Shantz, N. C., Sjostedt, S. J., van Donkelaar, A., Vlasenko, A., Wiebe, H. A., Xia, A. G., Zhang, J., Leaitch, W. R., and Abbatt, J. P. D.: Characterization of a large biogenic secondary organic aerosol event from eastern Canadian forests. Atmos. Chem. Phys., 10, 2825-2845, https://doi.org/10.5194/acp-102825-2010, 2010.

Spracklen, D. V., Carslaw, K. S., Kulmala, M., Kerminen, V.-M., Sihto, S.-L., Riipinen, I., Merikanto, J., Mann, G. W., Chipperfield, M. P., Wiedensohler, A., Birmili, W., and Lihavainen, H.: Contribution of particle formation to global cloud condensation nuclei concentrations, Geophys. Res. Lett., 35, L06808, https://doi.org/10.1029/2007GL033038, 2008.

Svenningsson, B., Arneth, A., Hayward, S., Holst, T., Massling, A., Swietlicki, E., Hirsikko, A., Junninen, H., Riipinen, I., Vana, M., Dal Maso, M., Hussein, T., and Kulmala, M.: Aerosol particle formation events and analysis of high growth rates observed above a subarctic wetland-forest mosaic. Tellus B, 60, 353-364, 2008.

Tiitta, P., Vakkari, V., Croteau, P., Beukes, J. P., van Zyl, P. G., Josipovic, M., Venter, A. D., Jaars, K., Pienaar, J. J., Ng, N. L., Canagaratna, M. R., Jayne, J. T., Kerminen, V.-M., Kokkola, H., Kulmala, M., Laaksonen, A., Worsnop, D. R., and Laakso, L.: Chemical composition, main sources and temporal variability of $\mathrm{PM}_{1}$ aerosols in southern African grassland, Atmos. Chem. Phys., 14, 1909-1927, https://doi.org/10.5194/acp-141909-2014, 2014.

Tröstl, J., Herrmann, E., Frege, C., Bianchi, F., Molteni, U., Bukowiecki, N., Hoyle, C. R., Steinbacher, M., Weingartner. E., Dommen, J., Gysel, M., and Baltensperger, U.: Contribution of new particle formation to the total aerosol concentration at the high-altitude site Jungfraujoch (3580 m asl, Switzerland), J. Geophys. Res.-Atmos., 121, 11692-11711, 2016.

Tunved, P., Strom, J., and Hansson, H. C.: An investigation of processes controlling the evolution of the boundary layer aerosol size distribution properties at the Swedish background station Aspvreten, Atmos. Chem. Phys., 4, 2581-2592, https://doi.org/10.5194/acp-4-2581-2004, 2004.
Tunved, P., Ström, J., and Krejci, R.: Arctic aerosol life cycle: linking aerosol size distributions observed between 2000 and 2010 with air mass transport and precipitation at Zeppelin station, Ny-Alesund, Svalbard, Atmos. Chem. Phys., 13, 3643-3660, https://doi.org/10.5194/acp-13-3643-2013, 2013.

Uttal, T., Makshtas, A., and Laurila, T.: The Tiksi International Hydrometeorological Observatory - An Arctic Members Partnership, WMO Bulletin, 62, 22-26, 2013.

Väänänen, R., Kyrö, E.-M., Nieminen, T., Kivekäs, N., Junninen, H., Virkkula, A., Dal Maso, M., Lihavainen, H., Viisanen, Y., Svenningsson, B., Holst, T., Arneth, A., Aalto, P. P., Kulmala, M., and Kerminen, V.-M.: Analysis of particle size distribution changes between three measurement sites in northern Scandinavia, Atmos. Chem. Phys., 13, 11887-11903, https://doi.org/10.5194/acp-13-11887-2013, 2013.

Vakkari, V., Laakso, H., Kulmala, M., Laaksonen, A., Mabaso, D., Molefe, M., Kgabi, N., and Laakso, L.: New particle formation events in semi-clean South African savannah, Atmos. Chem. Phys., 11, 3333-3346, https://doi.org/10.5194/acp-113333-2011, 2011.

Vakkari, V., Tiitta, P., Jaars, K., Croteau, P., Beukes, J. P., Josipovic, M., Kerminen, V.-M., Kulmala, M., Venter, A. D., van Zyl, P. G., Worsnop, D. R., and Laakso, L.: Reevaluating the contribution of sulfuric acid and the origin of organic compounds in atmospheric nanoparticle growth, Geophys. Res. Lett., 42, 1048610493, https://doi.org/10.1002/2015GL066459, 2015.

Vana, M., Komsaare, K., Hõrrak, U., Mirme, S., Nieminen, T., Kontkanen, J., Manninen, H. E., Petäjä, T., Noe, S. M., and Kulmala, M.: Characteristics on new-particle formation at three SMEAR stations, Boreal Environ. Res., 21, 345-362, 2016.

Venter, A. D., Vakkari, V., Beukes, J. P., Van Zyl, P. G., Laakso, H., Mabaso, D., Tiitta, P., Josipovic, M., Kulmala, M., Pienaar, J. J., and Laakso, L.: An air quality assessment in the industrialised western Bushveld Igneous Complex, South Africa, S. Afr. J. Sci., 108, 1-10, https://doi.org/10.4102/sajs.v108i9/10.1059, 2012.

Venter, A. D., Beukes, J. P., Van Zyl, P. G., Josipovic, M., Jaars, K., and Vakkari, V.: Regional atmospheric $\mathrm{Cr}$ (VI) pollution from the Bushveld Complex, South Africa, Atmos. Pollut. Res., 7, 762767, 2016.

Venzac, H., Sellegri, K., Villani, P., Picard, D., and Laj, P.: Seasonal variation of aerosol size distributions in the free troposphere and residual layer at the puy de Dôme station, France, Atmos. Chem. Phys., 9, 1465-1478, https://doi.org/10.5194/acp-9-1465-2009, 2009.

Wang, Z., Wu, Z., Yue, D., Shang D., Guo, S., Sun, J., Ding, A., Wang, L., Jiang, J., Guo, H., Gao, J., Cheung, H. C., Morawska, L., Keywood, M., and Hu, M.: New particle formation in China: Current knowledge and further directions, Sci. Total Environ., 577, 258-266, 2017.

Westervelt, D. M., Pierce, J. R., and Adams, P. J.: Analysis of feedbacks between nucleation rate, survival probability and cloud condensation nuclei formation, Atmos. Chem. Phys., 14, 5577 5597, https://doi.org/10.5194/acp-14-5577-2014, 2014.

Westervelt, D. M., Horowitz, L. W., Naik, V., Golaz, J.-C., and Mauzerall, D. L.: Radiative forcing and climate response to projected 21st century aerosol decreases, Atmos. Chem. Phys., 15, 12681-12703, https://doi.org/10.5194/acp-15-12681-2015, 2015 . 
Wiedensohler, A., Birmili, W., Nowak, A., Sonntag, A., Weinhold, K., Merkel, M., Wehner, B., Tuch, T., Pfeifer, S., Fiebig, M., Fjäraa, A. M., Asmi, E., Sellegri, K., Depuy, R., Venzac, H., Villani, P., Laj, P., Aalto, P., Ogren, J. A., Swietlicki, E., Williams, P., Roldin, P., Quincey, P., Hüglin, C., Fierz-Schmidhauser, R., Gysel, M., Weingartner, E., Riccobono, F., Santos, S., Grüning, C., Faloon, K., Beddows, D., Harrison, R., Monahan, C., Jennings, S. G., O’Dowd, C. D., Marinoni, A., Horn, H.-G., Keck, L., Jiang, J., Scheckman, J., McMurry, P. H., Deng, Z., Zhao, C. S., Moerman, M., Henzing, B., de Leeuw, G., Löschau, G., and Bastian, S.: Mobility particle size spectrometers: harmonization of technical standards and data structure to facilitate high quality long-term observations of atmospheric particle number size distributions, Atmos. Meas. Tech., 5, 657-685, https://doi.org/10.5194/amt-5-657-2012, 2012.

Wiedensohler, A., Wiesner, A., Weinhold, K., Birmili, W., Hermann, M., Merkel, M., Müller, T., Pfeifer, S., Schmidt, A., Tuch, T., Velarde, F., Quincey, P., Seeger, S., and Nowak, A.: Mobility Particle Size Spectrometers: Calibration Procedures and Measurement Uncertainties, Aerosol Sci. Technol., 52, 146-164, https://doi.org/10.1080/02786826.2017.1387229, 2017.
Wu, Z., Hu, M., Liu, S., Wehner, B., Bauer, S., Maßling, A., Wiedensohler, A., Petäjä, T., Dal Maso, M., and Kulmala, M.: New particle formation in Beijing, China: Statistical analysis of a 1-year data set, J. Geophys. Res., 112, D09209, https://doi.org/10.1029/2006JD007406, 2007.

Yu, F., Luo, G., Bates, T. S., Anderson, B., Clarke, A., Kapustin, V., Yantosca, R. M., Wang, Y., and Wu, S.: Spatial distributions of particle number concentrations in the global troposphere: Simulations, observations, and implications for nucleation mechanisms, J. Geophys. Res., 115, D17205, https://doi.org/10.1029/2009JD013473, 2010.

Yu, F., Luo, G., Pryor, S. C., Pillai, P. R., Lee, S. H., Ortega, J., Schwab, J. J., Hallar, A. G., Leaitch, W. R., Aneja, V. P., Smith, J. N., Walker, J. T., Hogrefe, O., and Demerjian, K. L.: Spring and summer contrast in new particle formation over nine forest areas in North America, Atmos. Chem. Phys., 15, 13993-14003, https://doi.org/10.5194/acp-15-13993-2015, 2015.

Zhang, R., Wang, G., Guo, S., Zamora, M. L., Ying, Q., Lin, Y., Wang, W., Hu, M., and Wang, Y.: Formation of urban fine particulate matter, Chem. Rev., 115, 3803-3855, 2015. 